\title{
Mandenkan
}

MANDENIKAN Bulletin semestriel d'études linguistiques mandé

\section{Verbal prefixes mà- and rà- in Susu and lexical features of verbal stems}

Préfixes verbaux mà- et rà- en susu et des traits lexicaux des bases verbales

ГЛАГОЛЬНЫЕ ПРИСТАВКИ та̀- И rà-

\section{Andrey Shluinsky}

\section{(2) OpenEdition Journals}

\section{Electronic version}

URL: https://journals.openedition.org/mandenkan/329

DOI: 10.4000/mandenkan.329

ISSN: $2104-371 \mathrm{X}$

\section{Publisher}

Llacan UMR 8135 CNRS/Inalco

\section{Printed version}

Date of publication: 1 December 2014

Number of pages: $73-110$

ISSN: 0752-5443

\section{Electronic reference}

Andrey Shluinsky, "Verbal prefixes mà- and rà- in Susu and lexical features of verbal stems", Mandenkan [Online], 52 | 2014, Online since 01 December 2014, connection on 08 July 2021. URL: http://journals.openedition.org/mandenkan/329 ; DOl: https://doi.org/10.4000/mandenkan.329 


\section{(C) 100}

Les contenus de Mandenkan sont mis à disposition selon les termes de la Licence Creative Commons Attribution - Pas d'Utilisation Commerciale - Partage dans les Mêmes Conditions 4.0 International. 


\section{Verbal prefixes mà- and rà- in Susu and lexical features of verbal stems}

Préfixes verbaux mà- et rà- en susu et des traits lexicaux des bases verbales

ГЛАГОЛЬНЫЕ ПРИСТАВКИ та̀- И rà-

\section{AUTHOR'S NOTE}

The paper is a revised version of a talk given at the $2^{\text {nd }}$ Conference on Mande languages in St.Petersburg in 2008. I am grateful to the audience for the fruitful discussion. The further research was conducted in terms of the projects supported by Russian Foundation for Humanities (grant No.12-34-01255) and by a grant of the President of Russian Federation (grant MK-3991.2012.6).

\section{Abbreviations}

ACT $=$ 'actualizer'

ASS $=$ assertive 


$$
\begin{aligned}
& \text { CONS = consecutive } \\
& \text { COP = copula } \\
& \text { EMPH = emphatic particle } \\
& \text { EXC = exclusive } 1^{\text {st }} \text { plural } \\
& \text { FOC = focal particle } \\
& \text { HABFUT = habitual-future } \\
& \text { INC = inclusive } 1^{\text {st }} \text { plural } \\
& \text { INDF = indefinite } \\
& \text { INF = infinitive } \\
& \text { intr = intransitive } \\
& \text { MA = the prefix mà- } \\
& \text { NEG = negation } \\
& \text { NMLZ = nominalization } \\
& \text { PL = plural } \\
& \text { POSS = possessivity } \\
& \text { PRF = perfect } \\
& \text { PROG = progressive } \\
& \text { PROH = prohibitive } \\
& \text { RA = the prefix } \text { rà- } \\
& \text { REC = reciprocal } \\
& \text { RETR = retrospective } \\
& \text { SBJV = subjunctive } \\
& \text { tr }=\text { transitive } \\
& \text { TRMN = terminative }
\end{aligned}
$$

\section{Introduction}

1 The prefixes mà- and rà- are the two most productive verbal prefixes in Susu. Although each of these two prefixes has a number of lexicalized idiomatic uses, both have a number of identifiable meanings. Moreover, the meaning of a prefixed verb can be predicted to a considerable degree from the lexical semantic features of the corresponding underived verb. This paper has two aims: the first, which is descriptive, is to systemize the available data on mà- and rà-; the second is to identify, for both prefixes, the relevant lexical features that influence the choice of the meaning with a given particular verb. For $m a \grave{-}$, a more detailed description is presented.

2 The third most frequent prefix in Susu, $i^{-}$, has a significantly lesser degree of productivity and, therefore, most $i$-derivates are lexicalized. Since no generalized meanings of $\dot{i}$ - can be made so far, the scope of this paper is limited to mà- and rà-.

The meanings of both Susu prefixes have been described earlier only by very general labels, cf. "modalité intentionnelle" for rà-, "modalité itérative" for mà- in (Houis 1963: 75; 78); "causative": "valence-increasing process by which a new Effector is added to the clause" for rà-, "distributive": "distributing a verb action over several participants", "can also distribute an event over a longer period of time then expected for the base verb" for mà- in (Lüpke 2005: 126; 127) for Jalonke, a language closely related to Susu. 
Both prefixes have parallel postpositions má and rá. Prefixes and corresponding postpositions have common etymologies and come back to nouns with locative meanings, cf. e.g. (Bailleul 1986) for the etymology of corresponding Bambara postpositions. A possible diachronic development scenario for both prefix mà- and postposition má has been proposed in (Šluinskij 2010).

In the context of Mande studies, the verbal prefixes in Susu are not unique, although the semantics of verbal prefixes and/or preverbs in Mande has not yet fallen in the focus of attention of linguists dealing with this language family. Keïta (1989) discusses verbal prefixes má-, rá- and $i$ - in Dialonke, a language closely related to Susu, but deals mainly with their morphophonology and tonal contour, rather than semantics. Kakabe prefixes corresponding to the Susu mà- and rà- are discussed by Vydrina (2009a; 2009b). Vydrin (2009) gives a detailed description of preverbs in Dan-Gweta. It is clear that verbal prefixes and/or preverbs in different Mande languages have different semantics and different morphosyntactic features.

In the context of general linguistics and linguistic typology, verbal prefixes in Mande are to be compared with European-type (Slavic, Romance, Germanic, Ossetic, Georgian, North Caucasian) systems of verbal prefixes and/or preverbs which have been studied thoroughly. Verbal prefixes in Mande are similar to European-type prefixes, but only to a certain extent. In both cases verbal prefixes and/or preverbs are derived diachronically to locative nouns, but unlike the prefixed verbs in European languages, Susu prefixed verbs have no synchronically detected locative semantics.

7 In my study I used available data from different sources: first-hand data from my consultant $^{1}$ (C) and secondary data from existing literature: (Raimbault 1923) (R), (Houis 1963) (H), (Fofana 1992) (F), (Touré 1994) (T). All the data were summarized and systematized in a single database. Since the data for mà- are not abundant, I give the entire lists of the attested derivates, while for rà- only sample examples are given. Considering the restricted set of data coming from different sources, I realize that sometimes my interpretation may be disputable.

8 The tonal contour of a verb changes when a prefix is added. This issue is not the focus of my study, since it has been discussed by Touré (1994: 232-233). According to his description, the prefixes mà- and rà- themselves in Susu always have a low tone, the first vowel of the verb has a high tone, and the subsequent vowels always have a low tone; lexical tones of the unprefixed verb are, therefore, ignored. Note however that Houis (1963: 69) reports a different tonal structure of Susu prefixed verbs; Keïta (1989) reports a different tonal structure of prefixed verbs in Dialonke.

9 Tonal marking in the existing descriptions of Susu is rather controversial. Since tones are not in the scope of my study (and were not checked), in the examples I simply mark lexical tones based on the description of Touré (1994), as this description is the most reliable.

\section{Prefix mà-}

\subsection{General overview}

Generally, the prefix mà- has been appropriately identified as an iterative / distributive marker. In the majority of cases this marker is used as a pluractional one that 
pluralizes an event in any sense. However, the types of pluralizing may be different. The resulting event may be distributive (i.e. involving a new participant for each repetition) or non-distributive (i.e. having a fixed set of participants for each repetition). The prefix mà- may be used for expressing both event-internal or eventexternal types of pluractionality, in terms of Cusic (1981), later accepted by Wood (2007). Normally, the prefix mà- is not used as a valency-changing tool (though there are exceptional cases). However, as a "by-product", it can either increase (1-2) or decrease (3-4) the verbal valencies.

\begin{tabular}{|l|l|l|l|}
\hline (1) & màlányì & bárà & yénsén \\
\hline & people & TRMN & disperse \\
\hline \multicolumn{3}{|l|}{ 'People dispersed.' (H:74) } \\
\hline
\end{tabular}

\begin{tabular}{|l|l|l|l|l|}
\hline (2) & dímé-è & bárà & gèmé & mà-yénsèn \\
\hline & child-PL & TRMN & stone & MA-disperse \\
\hline & \multicolumn{4}{|l}{} \\
\multicolumn{4}{|l}{ 'Children scattered the stones.' (H:74) } \\
\hline
\end{tabular}

\begin{tabular}{|l|l|l|l|l|l|l|}
\hline (3) & ń & bárà & ń & xúnyà & xùnyí & bíí \\
\hline & I & TRMN & I & younger_sibling & head & shave \\
\hline \multicolumn{5}{|l}{ 'I have shaved my younger brother. (H:70) } \\
\hline
\end{tabular}

\begin{tabular}{|l|l|l|l|l|}
\hline (4) & à & náxà & bírín & mà-bî \\
\hline & (s)he & cons & all & MA-shave \\
\hline \multicolumn{3}{|l}{} \\
\multicolumn{3}{|l}{ 'He shaved totally.' (H:70) } \\
\hline
\end{tabular}

\subsection{Derivates with an event-internal (multiplicative) meaning}

\subsubsection{Derivates with an event-internal (multiplicative) meaning in general}

11 The most frequent meaning of the prefix mà- is an event-internal pluractional meaning. It means that normally a mà-verb is a multiplicative one used to express an event that is internally plural and consists of a series of repeated sub-events. The corresponding unprefixed verb is used to express a single sub-event of such series.

12 Normally, mà-multiplicatives have the same argument structure as the corresponding unprefixed verbs. mà-multiplicatives fall into two classes: a) the less numerous multiplicatives proper (that retain the same set of participants for the whole series of sub-events, see \$2.2.2) and b) the more numerous multiplicative distributives (that involve different participants for different sub-events, see \$2.2.3). 
13 All the unprefixed verbs, from which the mà-multiplicatives are derived, have to be TELIC and (with two exceptions in the database, dégć 'sew' and xánín 'transport') express RELATIVELY BRIEF EVENTS. Note, however, that these brief events are not necessarily punctual, since at least some of them are compatible with Progressive and have, therefore, a durated phase before the natural endpoint, cf. (5).

\begin{tabular}{|l|l|l|l|l|l|}
\hline (5) & kùyéfúrè & ná & bòó-fè & à & má \\
\hline & perspiration & coP & tear-PROG & (s)he & at \\
\hline \multicolumn{4}{|l}{} \\
\multicolumn{4}{|l}{ 'His sweat is breaking him out.' (H:71) } \\
\hline
\end{tabular}

14 Another less trivial restriction is that all unprefixed verbs from which the màmultiplicatives are derived have to be TRANSITIVE (or labile used in the transitive sense).

\subsubsection{Multiplicatives proper}

Multiplicatives proper with the prefix mà- are derived from telic verbs that denote brief events WITH NO IRREVERSIBLE RESULT (this makes the repetition of the event with the same participants possible), cf. (6-7). There are 6 unprefixed verbs in the database, from which the mà-multiplicatives proper are derived:

- dògòtín 'pinch (once)' (T:194, 'pincer’²) > màdógòtìn 'pinch (repeatedly)' (T:214, 'pincer plusieurs fois');

- bònbó ‘beat' (H:71, ‘frapper'; T:189, 'frapper, battre') > màbónbj̀ ‘beat many times, flap' (H:71, 'tapoter')

- gárín 'beat, flap once' (T:182, 'taper, frapper') > màgárìn 'flap' (T:212, 'frapper plusieurs fois');

- sذ̀xó 'pierce; prick, sting' (T:181, 'percer, piquer') > màsóxò ‘slaughter' (H:82, 'poignarder');

- xín 'bite (once)' (T:176, 'mordre') > màxín ‘bite (repeatedly)' (T:208, 'mordre plusieurs fois');

- findí 'become, turn, change' (H:72, 'passer d'un état dans un autre, devenir'; R:123, 'tourner, devenir'; T:189, 'devenir') > màfíndì 'turn repeatedly' (H:72, 'changer d'état ou faire changer d'état plusieurs fois').

\begin{tabular}{|l|l|l|l|l|}
\hline (6) & nándén & náxà & mìxìdî & bònbó \\
\hline & stepmother & cons & orphan & beat \\
\hline & \multicolumn{3}{|l}{ 'The stepmother beat the orphan.' (H:122) } \\
\hline
\end{tabular}

\begin{tabular}{|l|l|l|l|l|l|l|l|l|l|}
\hline (7) & í & tó & nú & xìi-mà, & ń & náxà & sìgá & í & mà-bónbò-fè \\
\hline & you & when & RETR & sleep-HABFUT & I & cons & leave & you & MA-beat-PROG \\
\hline \multicolumn{7}{|l}{} \\
\hline
\end{tabular}




\subsubsection{Multiplicative distributives}

Multiplicative distributives with the prefix mà- are the most numerous group of the màderivations. They are derived from the telic verbs that denote some brief events WITH AN IRREVERSIBLE RESULT (sometimes this irreversibility is more pragmatic than logical). The lexical semantics of these verbs presumes a natural endpoint that cannot be cancelled. It is reasonable, therefore, that in an internally plural event a new participant is required for each sub-event, cf. (8-9), (10-11), (12-13). Sometimes an internally plural event is not purely distributive, but it is dispersive, because in each sub-event there is just a new part of / place for the same participant, cf. (14-15), (16-17), and not a different participant. There are 15 unprefixed verbs in the database, from which the mà- multiplicative distributives are derived:

- gbàlàntín 'tear out' (H:71, 'arracher qch. qui resiste') > màgbálàntìn 'tear out many objects' (H: 71, 'arracher');

• bánbán 'nail down' (H:70, 'enfoncer en cognant avec un instrument') > màbánbàn 'knock up, nail down in many places' (H:70, 'clouer en employant beaucoup de pointes');

- xábá 'cut' (T:179, 'couper') > màxábà 'shear, peel' (T:210, 'tondre, couper, coiffer');

• tálá 'pull out (once)?' (T:178, 'arracher') > màtálà 'pull out (many objects)?' (T:210, 'arracher');

• bòó 'cut, tear' (H:71, 'séparer, fendre, déchirer') > màbój̇ 'cut, tear in many places' (H:71, 'déchirer en plusieurs endroits'; T:206, 'éplucher');

• sùxú 'catch' (H:74, 'saisir, attraper') > màsúxù 'gather, collect many objects' (H:74, 'attraper en plusieurs fois, ramasser avec une pluralité de gestes');

- báá 'take down, pick' (T:174 'puiser, cueillir, ôter'; F:66, 'СРывать') > màbáà 'take down, pick many objects, clean' (F:66);

- xiri ' attach, be attached' (H:73, 'attacher') > màxírí 'attach many objects, tie up' (H:73, 'ficeler, panser, harnacher');

- fil 'give' > màfí 'distribute, waste' (H:72, 'donner largement, prodiguer');

• dòxó 'put, seat, sit' (H:72, 'poser, asseoir'; T:180, 's'asseoir') > màdóxว̀ 'put many objects, tell a story' (T:208, 'raconter, frequenter'; R:140, 'asseoir, raconter, dire');

• bálán 'close, be closed' (H:70, 'fermer, être fermé'; T:182, 'fermer') > màbálàn 'close many objects' (H:70, 'fermer quand il y a plusieurs ouvertures, ou encore une porte qui se rouvre toujours');

- tòngó 'take' (T:190, 'prendre') > màtóngò 'gather, collect' (T:211, 'ramasser');

• kj̀ó 'take down, take away' (H:73, 'enlever'; T:175, 'ramasser') > màkój̀ 'sweep' (H:73, 'balayer'; T:206, 'balayer');

• dégé 'sew' (H:71, 'coudre'; R:119, 'coudre') > màdégغ̀ 'sew in many places, resew' (H:71, 'arranger (pantalon)');

- xánín 'transport' (T:183, 'transporter, emporter') > màxánìn 'transport many objects' (T:213, 'transporter, emporter').

\begin{tabular}{|l|l|l|l|l|l|l|l|}
\hline (8) & à & làń, & í & xá & yí & bànànìbílì & gbàlàntín \\
\hline & (s)he & should & you & SBJv & this & banana_tree & tear_out \\
\hline & 'It is necessary that you tear out this banana tree.' (H:71) \\
\hline
\end{tabular}

\begin{tabular}{|l|l|l|l|l|}
\hline (9) & mùxú & sćxé & xáráxì & mà-gbálàntìn \\
\hline
\end{tabular}




\begin{tabular}{|l|l|l|l|l|}
\hline & we.EXc & herb & dry & MA-tear_out \\
\hline & '(Before we plant rice), we tear out dry herbs.' (H:71) \\
\hline
\end{tabular}

\begin{tabular}{|l|l|l|l|l|}
\hline$(10)$ & ná & bálán & sàábì & rá \\
\hline & this & close & key & with \\
\hline & \multicolumn{4}{|l}{ 'Lock this one.' (Lit. 'Close this one with a key'.) (H:70) } \\
\hline
\end{tabular}

\begin{tabular}{|l|l|l|}
\hline$(11)$ & nàdć-è & má-bálàn \\
\hline & door-PL & MA-close \\
\hline & 'Close the doors.' (H:70) \\
\hline
\end{tabular}

\begin{tabular}{|l|l|l|l|l|}
\hline$(12)$ & à & náxà & yéfúrè & tòngó \\
\hline & (s)he & CoNs & hot_water & take \\
\hline & \multicolumn{3}{|l}{ 'He took some hot water.' (H:89) } \\
\hline
\end{tabular}

\begin{tabular}{|l|l|l|l|l|}
\hline (13) & mìxì-é & ná & kánsí & mà-tóngò-fé \\
\hline & person-PL & CoP & peanut & MA-take-PROG \\
\hline & \multicolumn{3}{|l}{ 'People are collecting peanuts.' (F:72) } \\
\hline
\end{tabular}

\begin{tabular}{|l|l|l|l|l|l|}
\hline$(14)$ & à & mú & nòń & nàdé & bánbán-dè \\
\hline & (s)he & NEG & finish & door & nail_down-INF \\
\hline \multicolumn{6}{|c|}{ 'He did not finish nailing the door down.' (H:70) } \\
\hline
\end{tabular}

\begin{tabular}{|l|l|l|l|l|}
\hline (15) & kàmùdérí & bárà & kánkìrá & mà-bánbàn \\
\hline & carpenter & TRMN & box & MA-nail_down \\
\hline & 'The carpenter knocked the box up (by nailing it down in many places).' (F:72) \\
\hline
\end{tabular}

\begin{tabular}{|l|l|l|l|l|l|l|}
\hline$(16)$ & à & bárà & ń & má & dònmá & bòó \\
\hline & (s)he & TRMN & I & at & boubou & tear \\
\hline & \multicolumn{4}{|l}{} \\
\hline
\end{tabular}




\begin{tabular}{|l|l|l|l|l|l|}
\hline (17) & yókà & ndé & má-bóò & ń & bé \\
\hline & cassava & INDF & MA-tear & I & to \\
\hline & 'Slice some cassava for me.' (H:71) \\
\hline
\end{tabular}

The following facts seem to indicate that this semantic group of mà-derivates could diachronically be the starting point. Firstly, this group, though semantically complex, is the most numerous one. Secondly, this group includes the aforementioned dispersive subgroup and is therefore related to the locative semantics of the noun *ma that could be the lexical source of the prefix. However, synchronically it is appropriate to interpret $m \grave{a}-$ as a general pluractional marker, and to treat its multiplicative distributive meaning as triggered by specific semantic properties of an unprefixed verb.

There are two unprefixed verbs in this list, dégǵ 'sew' and xánín 'transport', that do not satisfy the condition of expressing a brief event, but still have the mà-derivates with a multiplicative distributive meaning, cf. (18-19).

\begin{tabular}{|l|l|l|l|l|}
\hline$(18)$ & à & xá & wàntányí & dégé-mà \\
\hline & (s)he & POSs & trousers & sew-HABFUT \\
\hline
\end{tabular}

\begin{tabular}{|l|l|l|l|l|l|l|l|l|}
\hline (19) & ń & xúnyà & gìnè & má & ná & ń & wàntányí & mà-d ́́gè-fè \\
\hline & I & younger_sibling & woman & at & COP & I & trousers & MA-sew-PROG \\
\hline \multicolumn{7}{|c|}{ 'My younger sister is mending my trousers.' (H:71) } \\
\hline
\end{tabular}

The mà- multiplicative distributive derived from kòó 'take down, take away' is strongly idiomatic, cf. (20-21).

\begin{tabular}{|l|l|l|l|l|l|l|}
\hline$(20)$ & à & náxà & káná & mòndé & kérén & kòó \\
\hline & (s)he & cons & sweet_stuff & handful & one & take_down \\
\hline \multicolumn{6}{|l}{ 'He took down one handful of sweet stuff.' (H:73) } \\
\hline
\end{tabular}

\begin{tabular}{|l|l|l|l|}
\hline$(21)$ & sìgá & xándćkúì & mà-kóò-dè \\
\hline & leave & yard & MA-take_down-INF \\
\hline & \multirow{2}{*}{ 'Go and sweep the yard.' (H:73) } \\
\hline
\end{tabular}




\subsubsection{Multiplicatives that are semantically equal to unprefixed stems} verbs with a multiplicative meaning make another numerous group of màmultiplicatives. In this case no apparent difference is attested between the unprefixed verbs' meaning and the corresponding mà-derivates' meaning, cf. (22-23). Presumably, the prefixed and unprefixed verbs are nevertheless different, but the difference can hardly be captured; it may be lexicalized and requires a further investigation. There are 10 unprefixed multiplicative verbs in the database from which the mà-multiplicatives with no semantic difference are derived:

• kòń 'lick' (H:22, 'lécher') > màkón 'lick' (T:208, 'lécher');

- géé ‘dig' (T:174, 'creuser') > màgée ‘dig' (T:206, 'deterrer, creuser');

- dìn 'pound' (H:72, 'donner des coups, piler', T:176, 'piler, heurter, cogner') > màdín 'pound' (H:72, 'piler dans un petit mortier');

- bórón 'trample, move one's legs' (H:71, 'agir avec des pieds'; T:182, 'piétiner') > màbóròn 'trample' (H:71, 'piétiner');

- sùnbú 'mix, blend, add' (T:190, 'mélanger, embrasser') > màsúnbù 'mix, blend' (T:211, 'mélanger');

- filin 'wrap' (T:182, 'enrouler') > màfilìn 'wrap' (T:212, 'enrouler, envelopper');

-yòlón 'fall one by one' (T:183, 'tomber un à un'; R:161, 'tomber, en parlant des feuilles d'arbres ou des graines') > màyólòn 'fall one by one' (T:212, 'tomber goutte a goutte');

- kàsán 'splash, scatter' (T:183, 'gicler, eclabousser') > màkásàn 'splash, scatter' (T:213, 'éparpiller');

- fintán 'fan, ventilate' (T:191, 'éventer') > màfíntàn 'fan, ventilate' (T:213, 'éventer');

- fùrùkú 'rub' (T:192, 'essuyer, frotter') > màfúrùkù 'rub' (T:214, 'essuyer, frotter, effacer').

\begin{tabular}{|l|l|l|l|l|}
\hline$(22)$ & à & ná & fúndényí & bórón-fè \\
\hline & (s)he & CoP & fonio & trample-PrOG \\
\hline & 'He is trampling fonio (to thresh it).' (H:71) \\
\hline
\end{tabular}

\begin{tabular}{|l|l|l|l|l|l|l|}
\hline$(23)$ & màlé & mà-bóròn-yì & témùi & ná & à & rà \\
\hline & rice & MA-trample-NMLZ & time & cop & (s)he & with \\
\hline & 'It is time to thresh the rice.' (H:71) \\
\hline
\end{tabular}

\subsubsection{Alternatives}

21 Alternatives with the prefix $m a ̀$ - are used to express multidirectional events and are derived from VERBS THAT EXPRESS MANNER OF MOTION, cf. (24-25). The mà-alternatives are derived from two unprefixed verbs found in the database:

- jéré 'move, go' (H:74, 'faire une marche') > mánérغ̀ ‘wander' (H:74, 'marcher longuement, se promener', $\mathrm{T}: 208$, 'se promener'); 
- gii 'move (intr), run' (H:73, 'courrir', T:174, 'courir, fuir') > màgî 'run around, go round' (H:73, 'courrir de-ci de-là, gambader, éviter quelqu'un').

This class of mà-derivates is not expected to be numerous, but one can expect to find out more mà-alternatives derived from the verbs that express other manners of motion.

\begin{tabular}{|l|l|l|l|l|}
\hline$(24)$ & sìi & bárà & á & gíi \\
\hline & goat & TRMN & (s)he & run \\
\hline & \multicolumn{4}{|l}{ 'The goat ran.' (F:40) } \\
\hline
\end{tabular}

\begin{tabular}{|l|l|l|l|l|}
\hline (25) & díídí & ndé & á & mà-gîi-fè \\
\hline & child & INDF & (s)he & MA-run-PROG \\
\hline & \multicolumn{3}{|l}{ 'A child is running about.' (c) } \\
\hline
\end{tabular}

\subsection{6. (Lexicalized) multiplicative-distributive causatives}

There are 6 mà-derivates in the database that are multiplicative-distributive causatives, i.e. they express an internally plural event that involves a new participant for each subevent and causes the event expressed by the corresponding unprefixed verb. These 6 unprefixed verbs do not form a natural class, so this meaning of the prefix mà- is lexicalized. Note that all 6 mà-derivates are to some extent idiomatic, cf. (26-27), (28):

- yénsén 'disperse (intr)' (H:74, 'disperser') > màyénsèn 'disperse to different places' (T:213, 'éparpiller');

• bòró 'rot, go bad' (H:71, 'pourrir', T:179, 'pourrir') > màbórò 'spoil everywhere' (H:71);

- tèe 'rise' (T:175, 'monter') > màtée 'pick up' (T:207, 'remonter, retrousser');

- dón 'eat' > màdón 'feed many beings, pasture' (H:72, 'faire manger'; T:207, 'faire manger, faire paitre');

- sòli 'push through' (H:74, 'percer, pointer, germer') > màsóli 'make holes, cut out' (H:74, 'faire des trous, percer, tailler en pointe (crayon), sculpter'; $\mathrm{T}: 210$, 'sculpter');

- dàngí 'pass' (H:71, 'passer, depasser'; R:118, 'traverser') > màdángì 'pass (tr) many objects, finger' ( $\mathrm{T}: 211$, 'faire passer, égrener').

\begin{tabular}{|l|l|l|l|}
\hline (26) & sànsí & bárà & sólì \\
\hline & seed & TRMN & push_through \\
\hline \multicolumn{4}{|c|}{ 'The seeds pushed through.' (H:74) } \\
\hline
\end{tabular}

\begin{tabular}{|l|l|l|l|l|l|l|l|}
\hline (27) & kámúdźrí & ná & wúrí & mà-sólì-fè, & á & xá & bálánsè \\
\hline & carpenter & COP & wood & MA-push_through-PROG & (s)he & SBJv & lock \\
\hline
\end{tabular}




\begin{tabular}{|l|l|l|l|l|l|l|l|}
\hline & bánbán & á & rá & & & & \\
\hline & nail_down & (s)he & with & & & & \\
\hline & 'The carpenter makes holes in the wood in order to nail down the lock.' (H:74) \\
\hline
\end{tabular}

\begin{tabular}{|l|l|l|l|l|l|l|l|}
\hline$(28)$ & á & sìgá-xì & màngé & xá & nìngé & dé & mà-dóǹ-dè \\
\hline & (s)he & leave-PRF & chief & Poss & bull & throat & MA-eat-INF \\
\hline \multicolumn{6}{|l}{} \\
\hline
\end{tabular}

\subsection{7. (Lexicalized) multiplicative causatives}

In the database there are 3 cases of $m \grave{a}$ - non-distributive multiplicative causatives, i.e. mà-derivates expressing an internally plural event that retains the same participants for all the sub-events and causes the event expressed by the corresponding unprefixed verb. The first two cases are clear, cf. (29-30) and (31-32), the third one is doubtful, cf. (33):

- bòròxó ‘be mild' (H:71, 'être mou') > màbóròxò ‘make mild doing a series of actions' (H:71, 'ramollir');

- dúlá 'drown (intr), go down, disappear' (H:72, 'disparaître dans l'eau, sombrer, se noyer'; T: 177, 's'enfoncer, se noyer') > màdúlà 'drown (tr) repeatedly' (H:72, 'submerger, se debattre dans l'eau, manquer de se noyer').

• ? dúndú 'keep silence' (T:188, 'se taire') > màdúndù 'calm (tr)' (T:211, 'calmer, consoler').

\begin{tabular}{|l|l|l|l|}
\hline$(29)$ & yí & mángò-è & bòròxó-xì \\
\hline & this & mango-PL & be_mild-PRF \\
\hline & \multicolumn{3}{|c|}{ 'These mangoes are mild.' (H:71) } \\
\hline
\end{tabular}

\begin{tabular}{|l|l|l|}
\hline$(30)$ & mùlùxúnyí & mà-bóròxò \\
\hline & lemon & MA-be_mild \\
\hline & 'Make the lemon mild (twisting it by foot).' (H:71) \\
\hline
\end{tabular}

\begin{tabular}{|l|l|l|l|}
\hline (31) & kúnkì & bárà & dúlá \\
\hline & ship & TRMN & drown \\
\hline & \multicolumn{3}{|l}{ 'The ship sank.' (H:72) } \\
\hline
\end{tabular}

\begin{tabular}{|l|l|l|l|l|l|l|}
\hline (32) & dímé-è & nú & ná & bèré-fè & bàré & mà-dúlà-fè \\
\hline
\end{tabular}




\begin{tabular}{|l|l|l|l|l|l|l|}
\hline & child-PL & RETR & COP & play-PROG & dog & MA-drown-PROG \\
\hline & 'The children played drowning the dog.' (H:72) \\
\hline
\end{tabular}

\begin{tabular}{|l|l|l|l|l|l|}
\hline$(33)$ & ń & tàrá & bárà & ń & mà-dúndù \\
\hline & I & elder_sibling & TRMN & I & MA-keep_silence \\
\hline \multicolumn{5}{|l}{} \\
\multicolumn{4}{|l}{ 'My brother calmed me.' (C) } \\
\hline
\end{tabular}

\subsection{8. (Lexicalized) discontinuatives}

There are two mà-derivates in the database that are discontinuatives, i.e. they express an event that takes place with pauses. The corresponding unprefixed verbs express uninterrupted events, cf. (34-35). These two unprefixed verbs do not form any natural class:

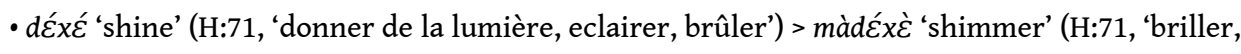
miroiter, resplendir');

• bèndún ‘drag, pull' (H:70, 'tirer'; T:191, ‘tirer') > màbćndùn 'drag, pull with intervals' (H:70, 'tirer par petits coups, tirailler').

\begin{tabular}{|l|l|l|l|l|}
\hline (34) & á & bèndún & ń & má \\
\hline & (s)he & pull & I & at \\
\hline & \multicolumn{3}{|l}{ 'Drag it to me.' (H:70) } \\
\hline
\end{tabular}

\begin{tabular}{|l|l|l|l|}
\hline (35) & wó & kúnkì & mà-bćndùn \\
\hline & you.PL & ship & MA-pull \\
\hline & 'Pull (with pauses) the ship!' (H:70) \\
\hline
\end{tabular}

\subsection{Derivates with a meaning of property}

\subsubsection{Derivates with a meaning of property in general}

The other pluractional meanings of $m a \dot{a}$ - are event-external. One of them is the meaning of property. This means that mà-derivates are used to express a general characteristic of an individual; in contrast, corresponding unprefixed verbs express related specific events.

Among the unprefixed verbs from which mà-properties are derived, there is a natural class of MENTAL STATES (kólón 'know, be acquainted with', gààxú 'be afraid of', tóóró 'suffer', kínikini 'feel pity's), but other verbs from which the mà-properties are derived do not form any natural class. 
Most of mà-properties have an argument structure which is different from the unprefixed verbs they are derived from, both decreasing and increasing the verb's valencies. This is evidently lexicalized, i.e. one cannot predict an argument structure of a prefixed verb from the argument structure or other features of the unprefixed verb from which it is derived.

Most of mà-properties denote externally-oriented properties, i. e. they are related not only to the subject of the verb, but also to other individuals. The exceptions are màsálàxùn 'make slippery' and màbòxùn 'spit constantly.'

\subsubsection{Properties}

mà-properties with no changes in the argument structure, cf. (36-37), are derived from 4 verbs in the database. One of them (màtínxìn 'educate') is considerably idiomatic:

- kàli 'swear' (H:73, 'jurer') > màkálì 'swear constantly' (H:73, 'jurer sans cesse');

- kíníkíní ‘feel pity’ (R:131, 'avoir pitié, avoir compassion’) > màkínikíni ‘be pitiful’ (T:215, 'être pitoyable');

• bòxún 'vomit, (?) spit' (H:71, 'vomir') > màbóxùn 'spit constantly' (H:71, 'cracher sans cesse');

- tìnxín 'be true, be right' (T:191, 'être juste, être droit') > màtínxìn 'educate' (T:214, 'redresser, eduquer').

\begin{tabular}{|l|l|l|l|l|l|l|l|}
\hline$(36)$ & á & nú & wèyćnyì & fàlá, & á & mú & kàlí-mà \\
\hline & (s)he & RETR & word & say & (s)he & NEG & swear-HABFUT \\
\hline & \multicolumn{6}{l}{} \\
\hline
\end{tabular}

\begin{tabular}{|l|l|l|l|}
\hline$(37)$ & bá & í & mà-kálì-fè \\
\hline & stop & you & MA-swear-PROG \\
\hline & \multicolumn{3}{|c|}{ 'Stop swearing every time.' (H:73) } \\
\hline
\end{tabular}

\subsubsection{Property passives}

313 mà-derivates in the database are property passives, i.e. they indicate properties and have a decreased valency compared to the corresponding unprefixed verbs. The subject of a mà- property passive corresponds to an object (in case of kólón 'know, be acquainted with'), cf. (38-39), or to a peripheral argument (in case of bèré 'play' and gààxú 'be afraid of'), cf. (40-41), of the corresponding unprefixed verb:

• kólón 'know, be acquainted with' (H:73, 'connaître'; T:182, 'connaître, savoir') > màkólòn 'be known by everyone' (H:73, 'être connu de tous');

- bèré ‘play’ (H:70, ‘jouer') > màbérè ‘be mocked' (H:70, ‘se jouer de, tourner en dérision');

- gààxú 'be afraid of' (H:73, 'avoir peur'; R:125, 'craindre, appréhender, avoir peur...') > màgááxù 'be terrible' (H:73, 'être terrifiant'; T:210, 'terrifier’).

\begin{tabular}{|l|l|l|l|l|}
\hline$(38)$ & ń & mú & yí & kólón-mà
\end{tabular}




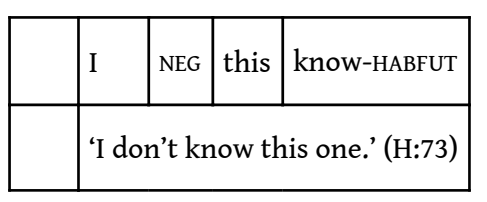

\begin{tabular}{|l|l|l|l|l|}
\hline$(39)$ & í & bárà & só & mà-kólòn-fè \\
\hline & you & TRMN & enter & MA-know-PROG \\
\hline & \multicolumn{4}{|c|}{ 'You became known by everyone.' (H:73) } \\
\hline
\end{tabular}

\begin{tabular}{|l|l|l|l|l|l|}
\hline$(40)$ & í & námà & gààxú & bàré & rá \\
\hline & you & PROH & be_afraid & dog & with \\
\hline & \multicolumn{4}{|l}{ 'Don't be afraid of the dog.' (H:73) } \\
\hline
\end{tabular}

\begin{tabular}{|l|l|l|l|}
\hline$(41)$ & yí & kúyé & mà-gááxù \\
\hline & this & idol & MA-be_afraid \\
\hline & \multicolumn{3}{|l}{ 'This idol is terrible.' (H:73) } \\
\hline
\end{tabular}

32 One more unprefixed verb has a labile mà-derivate that can be both property and property passive:

• yélé ‘laugh' (T:177, 'rire') > màyélè 'mock, be ridiculous' (T:208, ‘se moquer de, être drôle').

\subsubsection{Property causatives}

Another two mà-derivates in the database are property causatives, i. e. they express the events that cause properties related to the events expressed by the corresponding unprefixed verbs. The object of a mà- property causative corresponds to the subject of the unprefixed verb, cf. (42-43), (44-45):

• sáláxún 'glide' (H:74, 'glisser'; T:194, 'glisser, être gluant') > màsálàxùn 'make slippery' (H:74, 'rendre glissant, être glissant');

• tóóró ‘suffer' (Т:186, 'souffrir, déranger'; F:58, 'ПЕРЕЖИВАТЬ, СТРАДАТЬ, БЕСПОКОИТЬСя') > màtóórò 'make constantly suffer' (F:72, 'ЗАСТАВЛЯТЬ ТЕРПЕТЬ, СТРАДАТЬ').

\begin{tabular}{|l|l|l|l|l|l|}
\hline$(42)$ & á & bárà & sáláxún & mángáxórì & má \\
\hline & (s)he & TRMN & glide & mango_pit & at \\
\hline & \multicolumn{3}{|l}{ 'He slipped on a mango stone.' (H:74) } \\
\hline
\end{tabular}

\begin{tabular}{|l|l|l|l|l|}
\hline$(43)$ & tùné & bárà & bòxì & mà-sálàxùn \\
\hline
\end{tabular}




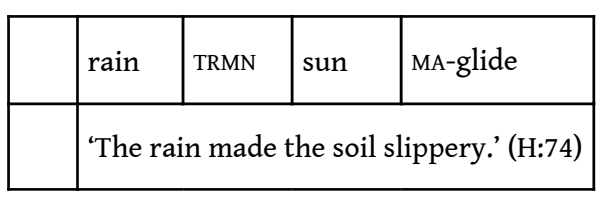

\begin{tabular}{|l|l|l|l|}
\hline (44) & ń & ná & tóóró-fe \\
\hline & I & coP & suffer-PROG \\
\hline & \multicolumn{3}{|l|}{ 'I am suffering.' (F:58) } \\
\hline
\end{tabular}

\begin{tabular}{|l|l|l|l|l|l|}
\hline (45) & sénì & bárà & á & ngá & mà-tóórò \\
\hline & Seni & TRMN & (s)he & mother & MA-suffer \\
\hline \multicolumn{5}{|l}{} \\
\hline \multicolumn{4}{|l}{ 'Seni made his mother (constantly) suffer.' (F:72) } \\
\hline
\end{tabular}

One more unprefixed verb has a labile mà-derivate that can be both property and property causative:

- tàngá 'escape' (C; T:190, 'éviter, échapper à') > màtángà 'avoid, protect' (T:211, 'éviter, sauvegarder').

\subsection{Derivates with a meaning of full coverage}

\subsubsection{Derivates with a meaning of full coverage in general}

Another meaning of the prefix mà- is the meaning of full coverage, where a mà-derivate is used to express an event which involves a participant entirely.

As it can be predicted, mà-derivates with the meaning of full coverage can be derived from the unprefixed verbs expressing the EVENTS WITH AN INCREMENTAL THEME in the sense suggested by Dowty (1991). ${ }^{4}$ It means that the progress of these events can be measured by the degree of participant involvement (that is called 'incremental theme'). In this case a mà-derivate denotes the natural endpoint where the participant is involved entirely.

There are unprefixed verbs which normally express events with no incremental theme that still have mà-derivates with the meaning of full coverage. However, in this case, the meaning of an unprefixed verb is reinterpreted as if the event still had an

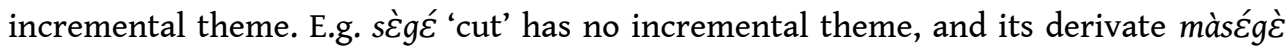
has the meaning of full coverage. This process is lexicalized, so it is not possible to explain why certain verbs undergo this process while the others do not.

Some of the mà-derivates with the meaning of full coverage differ in argument structure from the unprefixed verbs they are derived from, either decreasing or increasing in valency. This option is evidently a case of lexicalization. 


\subsubsection{Full coverage derivates}

mà-derivates with the meaning of full coverage with no changes in the argument structure, cf. (46-47), are derived from two verbs in the database:

- sc̀gé 'cut' (H:74, 'couper avec un instrument'; T:181, 'couper') > màsćgè 'cut all on a wide area' (H:74, 'couper sur une grande étendue');

- bàràbárá 'boil (intr)' (H:70, 'bouillir à gros bouillons, ébouillanter') > màbàràbàrà 'be boiled / ready, be scalded' (H:70).

\begin{tabular}{|l|l|l|l|}
\hline (46) & sìgá & túgí & sègé-dè \\
\hline & leave & palm_branch & cut-INF \\
\hline & 'Go and cut the palm branches.' (H:74) \\
\hline
\end{tabular}

\begin{tabular}{|l|l|l|l|l|l|l|l|}
\hline$(47)$ & wón & mìní-mà & xर́ & má, & wón & xá & mà-sćgè \\
\hline & we.INC & exit-HABFUT & field & at & we.INC & SBJV & MA-cut \\
\hline & 'We shall go to the field to uproot it completely.' (H:74) \\
\hline
\end{tabular}

\subsubsection{Full coverage passives}

There are two mà-derivates in the database that are full coverage passives, i.e. they express the meaning of full coverage and have a decreased valency compared to the corresponding unprefixed verbs. The subject of a mà- property passive corresponds to the object of the unprefixed verb, cf. (48-49):

- bii 'cut, root out, shave' (H:70, 'couper (herbes), défricher, raser (poils)'; T:174, 'raser, sarcler') > màbû 'cut, shave oneself completely' (H:70, 'raser dans tous les sens, ou complètement'; T:206, 'raser, sarcler');

• tòlín 'twist' (H:74, 'faire des torsions'; T:184, 'tordre') > màtólìn 'be twisted completely' (H:74).

\begin{tabular}{|l|l|l|l|l|}
\hline$(48)$ & á & ná & dùgí & tòlín-fè \\
\hline & (s)he & coP & cloth & twist \\
\hline & \multicolumn{4}{|c|}{ 'She is squeezing the cloth.' (H:74) } \\
\hline
\end{tabular}

\begin{tabular}{|l|l|l|l|}
\hline (49) & yí & wúrí & mà-tólìn-xì \\
\hline & this & branch & MA-twist-PRF \\
\hline & \multicolumn{3}{|c|}{ 'This branch is completely twisted.' (H:74) } \\
\hline
\end{tabular}




\section{5. (Lexicalized) derivates with a more abstract lexical meaning}

\subsubsection{Derivates with a more abstract lexical meaning in general}

41 There is a relatively large group of mà-derivates with a more abstract/general meaning than the unprefixed verbs they are derived from. This group is strongly idiomatic and lexicalized. It is impossible to predict the meaning of a mà-derivate of this group from the meaning of the corresponding unprefixed verb, neither it is possible to predict if a given verb has a mà-derivate with a more abstract meaning.

Some of the mà-derivates with a more abstract lexical meaning have an argument structure different from the unprefixed verbs from which they are derived, thus having an increased valency.

\subsubsection{Derivates with a more abstract meaning}

mà-derivates with a more abstract lexical meaning and with no changes in the argument structure, cf. (50-51), are derived from 7 verbs in the database:

- sàrá 'buy, sell' (R:151, 'préparer, vendre, acheter') > màsárà 'exchange’(T:209, 'échanger, transformer'; R:142, 'changer, transformer');

- xínbéli 'be cold' > màxínbèli 'be cold, quiet, slow' (T:214, 'être calme, lent, refroidir');

- kàná 'spoil' (T:180, 'gâter') > màkánà 'dissipate, waste' (T:209, 'gaspiller');

- wáá 'cry, want' (T:175, 'pleurer, vouloir') > màwáà 'complain' (T:207, 'se plaindre');

- tìnkán 'study' (T:191, 'apprendre, initier') > màtínkàn 'learn' (C);

- xóróxó ‘be hard, difficult’ (T:192, 'être dur, difficile’) > màxóròxò ‘be resistant, oppose' (T: 214 , 'être resistant');

- xćć ‘send on a mission' (T:175, 'envoyer en commission') > màxćc̀ 'commit, charge with' (T: 207 , 'confier à, mettre à la charge de').

\begin{tabular}{|l|l|l|l|l|l|}
\hline (50) & tòxé & kérén & sàrá & ń & má \\
\hline & hen & one & buy & I & at \\
\hline & \multicolumn{4}{|c|}{ 'Buy / sell me a hen.' (R:151) } \\
\hline
\end{tabular}

\begin{tabular}{|l|l|l|l|l|l|l|}
\hline$(51)$ & é & bárà & ń & má & búkí & mà-sárà \\
\hline & they & TRMN & I & at & book & MA-buy \\
\hline \multicolumn{6}{|l}{ 'They exchanged my book.' (F:60) } \\
\hline
\end{tabular}

\subsubsection{Causatives with a more abstract meaning}

Two mà-derivates in the database are causatives with a more abstract lexical meaning, i.e. they express events that cause more general events than those expressed by the corresponding unprefixed verbs. The object of a mà- causative with a more abstract 
lexical meaning corresponds to the subject of an unprefixed verb, cf. (52-53), (54-55). A further possibility is a reflexive use of the causative mà-derivate (56):

- kánkán 'attach (intr)' (H:73, 'accrocher') > màkánkàn 'attach, guard, save' (H:73, 'accrocher, garder'; T:213, 'mettre en détention, conserver');

- gòró 'go down, descend' (T:180. 'descendre') > màgórò 'diminish, lower' (T:208, 'abaisser, s'asseoir').

\begin{tabular}{|l|l|l|l|l|l|}
\hline (52) & á & bárà & kánkán & wúrí & má \\
\hline & (s)he & TRMN & attach & wood & at \\
\hline & \multicolumn{4}{|c|}{ 'He is tied to wood (Il est accroché à l'arbre).' (H:73) } \\
\hline
\end{tabular}

\begin{tabular}{|l|l|l|l|l|l|l|}
\hline (53) & á & bárà & ń & má & kóbìrì & mà-kánkàn \\
\hline & (s)he & TRMN & I & at & money & MA-attach \\
\hline & \multicolumn{3}{|l}{ 'He guarded my money.' (H:73) } \\
\hline
\end{tabular}

\begin{tabular}{|l|l|l|l|}
\hline (54) & kùlé & bárà & gòró \\
\hline & monkey & TRMN & descend \\
\hline & \multicolumn{3}{|c|}{ 'The monkey climbed down.' (F:78) } \\
\hline
\end{tabular}

\begin{tabular}{|l|l|l|l|l|l|}
\hline$(55)$ & ń & tàrá & bárà & á & mà-górò \\
\hline & I & elder_sibling & TRMN & (s)he & MA-descend \\
\hline \multicolumn{4}{|l}{ 'My brother decreased it.' (C) } \\
\hline
\end{tabular}

\begin{tabular}{|l|l|l|l|}
\hline (56) & í & mà-górò & bé \\
\hline & you & MA-descend & here \\
\hline & \multicolumn{2}{|c|}{ 'Sit down here.' (H:64) } \\
\hline
\end{tabular}

One more unprefixed verb has a labile mà-derivate with a more abstract lexical meaning that can express both a more general event and a causation of it:

- kúyá 'be big, be long' (T:178, 'être grand, être long') > màkúyà 'be distant, make distant' (T: 209, ‘éloigner, être loin').

\section{6. (Lexicalized) derivates with an intensive meaning}

There are four mà-derivates that express more intensive events than the unprefixed verbs they are derived from, cf. (57-58). These unprefixed verbs do not form any 
natural class: two of them express activities, one of them designates a permanent state, and another one is a stative verb of perception. The exact meaning is defined lexically:

- nááxú 'be bad' (H:73, 'être mauvais, méchant'; T:185, 'être méchant') > mànááxù 'be very bad' (H:74, 'être devenu méchant, insupportable'; T:210, 'être déteste');

- gèrún 'swallow' (T:183, 'avaler') > màgérùn 'swallow quickly and greedily' ( $\mathrm{T}: 212$, 'avaler rapidement et avidement');

• xàa 'wash' (H:73, 'laver'; T:175, 'laver') > màxáá 'wash; wash thoroughly' (H:73, 'laver en frottant beaucoup, avec du savon');

• tóó ‘see' (C; T:175, 'voir, apercevoir') > màtóò 'look' (C; T:207, 'regarder, examiner').

\begin{tabular}{|l|l|l|l|}
\hline (57) & yí & bàré & nááxú \\
\hline & this & dog & be_bad \\
\hline & \multicolumn{3}{|c|}{ 'This dog is (permanently) angry.' (H:73) } \\
\hline
\end{tabular}

\begin{tabular}{|l|l|l|l|}
\hline (58) & nààrí & mà-nááxù & hán \\
\hline & cat & MA-be_bad & very \\
\hline & 'The cat is (permanently) very, very angry.' (H:74) \\
\hline
\end{tabular}

47 xàa 'wash' has an unclear status in this list: the data of Houis (1963) contain clear intensive uses of màxáà, cf. (59-60), but my own first-hand data (61), as well as the data of Fofana (1992) (62), give no intensive meaning of this derivate. One can assume a semantic shift since Houis (1963).

\begin{tabular}{|l|l|l|l|l|}
\hline (59) & á & sìgá-xì & dùgí-è & xàá-dè \\
\hline & (s)he & leave-PRF & cloth-PL & wash-INF \\
\hline & \multicolumn{4}{|c|}{ 'She went to wash the clothes.' (H:73) } \\
\hline
\end{tabular}

\begin{tabular}{|l|l|l|l|l|l|l|}
\hline$(60)$ & sàfún-yí & mà-xáà & nàn & rà-fán & ń & má \\
\hline & soap-ACT & MA-Wash & EMPH & RA-be_good & I & at \\
\hline & 'I like fine washing with soap.' (H:73) \\
\hline
\end{tabular}

\begin{tabular}{|l|l|l|l|l|l|}
\hline (61) & ń & tàrá & bárà & á & mà-xáà \\
\hline & I & elder_sibling & TRMN & (s)he & MA-wash \\
\hline \multicolumn{5}{|c|}{ 'My brother washed himself.' (C) } \\
\hline
\end{tabular}




\begin{tabular}{|l|l|l|l|l|}
\hline$(62)$ & ń & ná & ń & mà-xáà-fè \\
\hline & I & COP & I & MA-wash-PROG \\
\hline & 'I am washing myself.' (F:73) \\
\hline
\end{tabular}

màtóo 'look', derived from tóó 'see', is a special lexicalized case of the intensive meaning where a state is converted into an activity, cf. (63-64).

\begin{tabular}{|l|l|l|l|l|l|}
\hline$(63)$ & ń & bárà & ń & tàrá & tóó \\
\hline & I & TRMN & I & elder_sibling & see \\
\hline \multicolumn{4}{|l}{} \\
\multicolumn{3}{|l}{ 'I saw my brother.' (C) } \\
\hline
\end{tabular}

\begin{tabular}{|l|l|l|l|l|l|}
\hline$(64)$ & ń & ná & ń & tàrá & mà-tóò-fè \\
\hline & I & COP & I & elder_sibling & MA-see-PROG \\
\hline \multicolumn{4}{|l}{} \\
\hline \multicolumn{4}{|l}{ 'I am looking at my brother.' (C) } \\
\hline
\end{tabular}

\section{7. (Lexicalized) attenuatives}

There are $3 m$ ma-derivates in the database that are attenuatives, i.e. they express a reduced event in comparison to the one expressed by the unprefixed verb. All the three unprefixed verbs attested to have two attenuative mà-derivates are VERBS OF DIRECTED мотіоN, so their derivates express a shorter motion than the standard motion expressed by the unprefixed verbs, cf. (65-66), (67-68):

• sigá 'leave' > màsígà 'move away from smb./smth.' (H:74, 's’écarter de, se pousser, reculer'; T: 209, 'éloigner, reculer, déplacer');

- fáá 'come' (T:174, 'venir') > màfáa 'approach' (T:206, 'approcher');

- sóó 'enter' > màsóó 'come near, approach' (H:74, 'faire entrer dans un groupe, un tas; approcher, avancer près de'; T:207, 's'approcher, s'habiller').

\begin{tabular}{|l|l|l|l|l|l|}
\hline$(65)$ & ń & tàrá & bárà & sìgá & Kónákírí \\
\hline & I & elder_sibling & TRMN & leave & Conakry \\
\hline \multicolumn{5}{|c}{ 'My brother left for Conakry.' (c) } \\
\hline
\end{tabular}

\begin{tabular}{|l|l|l|l|l|}
\hline$(66)$ & ń & mà-sígà-mà & wó & rá \\
\hline & I & MA-leave-HABFUT & you.PL & with \\
\hline & \multicolumn{3}{|c|}{ 'I'll move away from you (Je m'écarterai de vous).' (H:74) } \\
\hline
\end{tabular}




\begin{tabular}{|l|l|l|l|l|}
\hline$(67)$ & ń & bárà & sóó & bànxí \\
\hline & I & TRMN & enter & house \\
\hline & \multicolumn{3}{|c|}{ 'I came home / I entered the house.' (C) } \\
\hline
\end{tabular}

\begin{tabular}{|l|l|l|l|l|l|}
\hline (68) & mà-sóò, & ń & xá & xúi & mé \\
\hline & MA-enter & I & SBJV & voice & hear \\
\hline & 'Get closer to me so that I can hear your voice.' (H:74) \\
\hline
\end{tabular}

\subsection{Derivates with peripheral meanings}

\subsubsection{Derivates with peripheral meanings in general}

In this section the meanings of mà-derivates that are attested only for 1-2 verbs are listed when the semantic correlations of the mà-derivates and the unprefixed verbs they are derived from are clear. I assume that, since the semantic correlations are clear, one can expect more verbs in each group (of course, as well as in the main groups discussed in the previous sections); that is why, technically, subsections containing a single verb are created.

\subsection{2. (Lexicalized) dispersives}

There is one mà-derivate in the database that is a dispersive, i.e. it is used to express the fact that an event takes place in different locations, cf. (69-70). As opposed to a more numerous group containing dispersive multiplicative distributives, here the events taking place in different locations do not have to occur jointly and therefore are not necessarily sub-events of a single event:

- fúntú 'distend, swell up' (H:72, 'enfler, gonfler') > màfúntù ‘distend, swell up everywhere' (H:

72 , 'enfler de partout').

\begin{tabular}{|l|l|l|l|l|}
\hline$(69)$ & ń & bèlèxé & bárà & fúntú \\
\hline & I & arm & TRMN & swell_up \\
\hline & \multicolumn{3}{|l}{ 'My arm swelled up.' (H:72) } \\
\hline
\end{tabular}

\begin{tabular}{|l|l|l|l|l|l|}
\hline$(70)$ & á & sànyí & bírín & mà-fúntù-mà & nè \\
\hline & (s)he & leg & all & MA-swell_up-HABFUT & ASS \\
\hline & \multicolumn{6}{|c|}{ '(If a woman is pregnant for the first time), her legs swell up everywhere.' (H:72) } \\
\hline
\end{tabular}




\subsection{3. (Lexicalized) frustratives}

Another mà-derivate in the database is a frustrative, i. e. it is used to express an event that takes place in vain, in contrast to a normal event expressed by the unprefixed verb, cf. (71-72). The only unprefixed verb that has a mà-derivate with a frustrative meaning is a verb of activity, and the derivate denotes a vain activity:

- fén ‘look for' (H:72, 'aller chercher'; T:175, 'chercher') > màfén ‘look for in vain' (H:72).

\begin{tabular}{|l|l|l|l|l|}
\hline$(71)$ & á & náxà & yèlìbá-è & fén \\
\hline & (s)he & cons & griot-PL & look_for \\
\hline & 'He went to look for griots.' (H:72) \\
\hline
\end{tabular}

\begin{tabular}{|l|l|l|l|l|l|l|l|l|l|}
\hline (72) & í & tàn & nàn & bárà & é & mà-féǹ, & kónó & é & sìgá-xì \\
\hline & you & FOC & EMPH & TRMN & they & MA-look_for & but & they & leave-PRF \\
\hline
\end{tabular}

\subsection{4. (Lexicalized) pejoratives}

One more mà-derivate in the database is pejorative, i.e. it is used to express an event that has a negative evaluation, in contrast to the neutral event:

- fàlá 'say' (T:180, 'dire, tresser') > màfálà 'criticize, slander' (T:208, 'critiquer, médire').

\subsubsection{Derivates from non-verbal parts of speech}

54 The prefix $m \grave{a}$ - is also occasionally used as a verbalizer that derives verbs from other parts of speech:

- tààli 'parable, proverb' (R:155, 'parabole, proverbe'; T:84, 'proverbe, fable') > màtááli 'tell' (T: 210, 'raconter');

- yándì 'please' (H:121, 's'il te plâit'; R:160, ‘s'il te plât') > màyándì ‘beg pardon' (T:211, 'prier, demander pardon').

\subsection{Unclear cases}

55 A number of mà-derivates have an unclear (so far) semantic correlation with the unprefixed verbs they are derived from. In most cases the meaning that is added by the prefix mà- to the lexical meaning of the corresponding unprefixed verb is difficult to identify mainly because of insufficient data (therefore, this is to be fixed during further research). 


\subsubsection{Activities semantically close to unprefixed verbs}

There are four $m \grave{a}$-derivates in the database that are used to express activities which are semantically equal or close to the activities expressed by the corresponding unprefixed verbs:

- kérí 'pursue, chase' (T:177, 'chasser, poursuivre') > màkérì 'pursue, relieve' (T:209, 'poursuivre, venir en aide');

- kiítí 'judge' (T:185, 'juger, aller en justice') > màkíitì 'judge' (T:211, 'juger, aller en justice');

- ságátá 'follow, pursue' (T:192, 'suivre, rejoindre’) > màságàtà 'pursue' (T:214, 'poursuivre, rejoindre');

- gìlín 'roast, fry' (T:183, 'griller, rôtir') > màgílin 'roast, fry' (T:212, 'griller, rôtir').

\subsubsection{Accomplishments semantically close to unprefixed stems}

There are three mà-derivates in the database that are used to express accomplishments which are semantically equal or close to the accomplishments expressed by the corresponding unprefixed verbs:

• sòtó 'get, obtain' ( $\mathrm{T}: 181$, 'recevoir, obtenir') > màsót ’get, obtain, possess' (T:210, 'recevoir, obtenir, posséder');

-yòntón 'decrease tension' (T:191, 'diminuer de tension') > màyóntòn 'weaken' (T:213, 'détendre');

- yànfá 'betray, distract, deceive' ( $\mathrm{T}: 189$, 'trahir, distraire, tromper') > màyánfà 'distract, deceive' (T:211, 'distraire, tromper').

Possibly, mà-derivates expressing activities and accomplishments which are semantically equal or close to those expressed by the unprefixed verbs they are derived from, are obtained from the desemantization of mà-intensives (cf. the aforementioned case of xàa 'wash' > màxàà 'wash thoroughly', later '? wash') or mà-derivates with other meanings, but more data and further research are needed to verify this.

\subsubsection{Derivates with an internally plural participant}

Another mà-derivate in the database has a participant with an internally plural structure unlike the unprefixed verb from which it is derived, cf. (73-74):

- bilín 'encircle' (H:70, 'entourer, cerner') > màbilìn 'go round' (H:70, 'tourner autour'; T:212, 'contourner, tourner autour').

\begin{tabular}{|l|l|l|l|l|}
\hline (73) & dònsoé-è & bárà & sílí & bìlín \\
\hline & hunter-PL & TRMN & elephant & encircle \\
\hline & \multicolumn{4}{|c}{ 'Hunters surrounded the elephant.' (H:70) } \\
\hline
\end{tabular}

\begin{tabular}{|l|l|l|l|l|l|}
\hline$(74)$ & ń & bárà & yí & gèmèkóntà & mà-bílìn \\
\hline & I & TRMN & this & stone_heap & MA-encircle \\
\hline \multicolumn{6}{|c|}{ 'I went around this heap of stones.' (H:70) } \\
\hline
\end{tabular}




\subsubsection{Transitives and causatives}

60

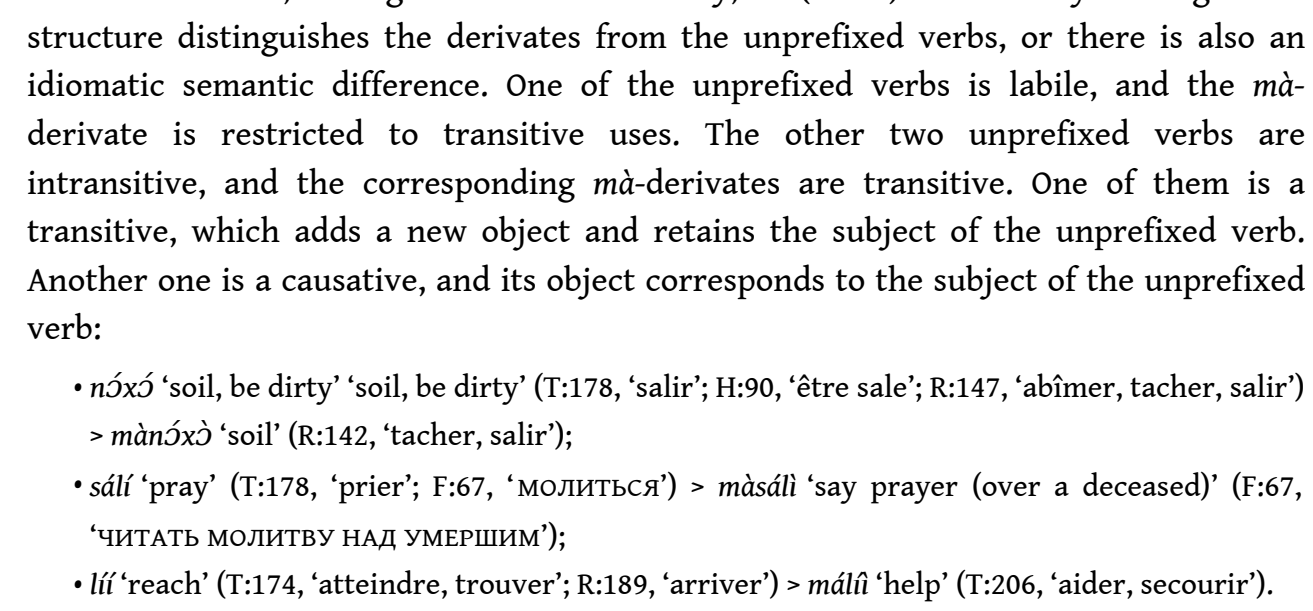

are derived from, having an increased valency,

\begin{tabular}{|l|l|l|l|l|}
\hline$(76)$ & é & bárà & fùré & mà-sálì \\
\hline & they & TRMN & deceased & MA-pray \\
\hline & \multicolumn{4}{|c|}{ 'They said a prayer over the deceased.' (F:67) } \\
\hline
\end{tabular}

\subsubsection{Other unclear cases}

In the other four unclear cases of mà-derivates no generalization can be made at all. Intuitively, in contrast to fully idiomatic cases discussed below, here the meanings of unprefixed verbs and their mà-derivates are interrelated, but in a very obscure way, cf. (77-78):

- kótó 'put one on another, stack' (H:73, 'mettre les choses les unes sur les autres'; T:178, 'entasser, empiler') > màkótò 'close' (T:209, 'couvrir, recouvrir');

- dàxú 'be absent-minded' (T:179, 'être fou') > màdáxù 'deceive, disappoint' (T:208, 'tromper');

- fán 'be good' (T:175, 'être bon') > màfán ‘be loved' (T:207, 'être aimé');

- gàlànbú 'disagree, cross' (T:195, 'se manquer, être en désaccord, croiser') > màgálànbù 'cross, mix' (T:214, 'croiser, mélanger').

\begin{tabular}{|l|l|l|}
\hline (77) & yègé & kótó \\
\hline & wood & stack \\
\hline
\end{tabular}


'Stack the wood.' (H:73)

\begin{tabular}{|l|l|l|}
\hline (78) & bàndé & mà-kótò \\
\hline & rice & MA-stack \\
\hline & 'Cover the rice (that is in the calabash).' (H:73) \\
\hline
\end{tabular}

\subsection{Fully idiomatic derivates}

Finally, a considerable group of mà-derivates are fully idiomatic, i.e. there is no synchronic semantic relation between them and the unprefixed verbs they are derived from, cf. (79-80), (81-82), (83-84):

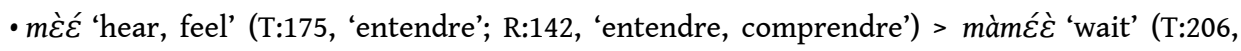
'attendre');

• sáá 'put, lie down' (T:174, 'mettre, poser, coucher'; R:150', placer, mettre, déposer, se coucher') > màsáà 'swim, make love' (T:207, 'nager, faire l'amour avec');

- tèlèxún 'carry on one's head' (T:194, 'porter qch. sur la tête sans le tenir des mains') > màtélèxùn 'be eloquent' (T:214, 'être éloquent');

•kÉnÉn 'please' (T:182, 'plaire'; R:130 'plaire, être agréable') > màkÉnżn 'clarify' (T:213, 'affirmer, clarifier');

- níná ‘do' (T:178, 'faire') > mànínà 'be similar' (T:209, 'essayer, goûter, mésurer, ressembler à);

- xónó 'get angry' (C; T:179, 'se fâcher, être amer') > màxónò 'injure' (T:210, 'blesser');

- làn 'agree, be necessary, must' (T:176, 'être d'accord, falloir') > màlán 'convoke, join' (T:208, 'rassembler, reunir').

\begin{tabular}{|l|l|l|l|l|}
\hline$(79)$ & á & kùré & xílísí & mèć-mà \\
\hline & (s)he & tortoise & smell & feel-HABFUT \\
\hline \multicolumn{3}{|l}{ 'He will feel a tortoise's smell.' (H:55) } \\
\hline
\end{tabular}

\begin{tabular}{|l|l|l|l|l|}
\hline$(80)$ & ń & nú & á & mà-méc̀-fè \\
\hline & I & RETR & (s)he & MA-feel-PROG \\
\hline & \multicolumn{4}{|c|}{ '(While my brother was writing a letter), I was waiting for him.' (C) } \\
\hline
\end{tabular}

\begin{tabular}{|l|l|l|l|l|}
\hline$(81)$ & á & sáá-xì & kóóláá & búnyí \\
\hline & (s)he & lie_down & cola & under \\
\hline \multicolumn{4}{|l}{ 'He is lying under the cola tree.' (H:58) } \\
\hline
\end{tabular}




\begin{tabular}{|l|l|l|l|l|l|l|l|l|l|}
\hline$(82)$ & sónć & gbégbè & ná & bé, & ń & mú & nòó-mà & yé & mà-sáà-dè \\
\hline & crocodile & many & COP & here & I & NEG & can-HABFUT & this & MA-lie_down-INF \\
\hline
\end{tabular}

\begin{tabular}{|l|l|l|l|l|l|l|}
\hline (83) & ń & bárà & xónó & ń & tàrá & má \\
\hline & I & TRMN & get_angry & I & elder_sibling & at \\
\hline \multicolumn{7}{|l}{ 'I got angry with my brother.' (C) } \\
\hline
\end{tabular}

\begin{tabular}{|l|l|l|l|l|l|}
\hline$(84)$ & ń & bárà & ń & tàrá & mà-xónò \\
\hline & I & TRMN & I & elder_sibling & MA-get_angry \\
\hline \multicolumn{4}{|l}{} \\
\multicolumn{4}{|l}{ 'I injured my brother.' (C) } \\
\hline
\end{tabular}

\subsection{Prefix mà-: conclusion}

A description of the prefix mà- semantics in Susu is given in \$2.2-2.10.

There is an evident core group of mà-derivates, mà-multiplicatives. Their main subgroups are multiplicatives proper, multiplicative distributives, multiplicatives semantically equal to unprefixed stems and alternatives. The type of the semantic subgroup of the core group can always be predicted from its lexical features:

- transitive telic verbs that express brief events with no irreversible result have multiplicative proper mà-derivates;

- transitive telic verbs that express brief events with an irreversible result have multiplicative distributive mà-derivates;

- multiplicative unprefixed verbs have multiplicative mà-derivates with no apparent change of the lexical meaning;

- verbs of motion manner verbs have alternative mà-derivates.

In the non-core groups of mà-derivates there are also correlations between the lexical meaning of a verb and the meaning of its mà-derivate:

-verbs that express mental states have mà-derivates with the meaning of property;

- mà-derivates with an incremental theme have mà-derivates with the meaning of full coverage;

- verbs of directed motion have attenuative mà-derivates.

These correlations are less strong, because unlike the correlations of the core group, they can be confused by lexicalization: e.g. the verb with an incremental theme dón 'eat' has no expected mà-derivate with the meaning of full coverage, but has a lexicalized mà- multiplicative-distributive causative màdón 'feed many beings, pasture'.

Other unprefixed verbs which do not participate in the discovered correlations (mainly, non-motional activities, non-brief non-incremental accomplishments), have màderivates that are lexically distributed between the mentioned groups (mà-derivates 
with different types of multiplicative meanings, with the meanings of property, of full coverage, of attenuative) and lexicalized groups.

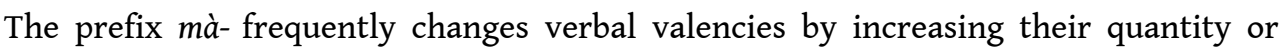
more marginally by decreasing it. Normally, the valency-changing effect is an addition to the meaning of the prefix and not its proper function. The process of the valencychanging by $m a ̀$ - is lexicalized, and not incited by any general factors.

\section{Prefix rà-}

\subsection{General overview}

Generally, the prefix rà- was fairly identified earlier as a causative marker. In the majority of cases this marker is used as a valency-increasing one that adds (at least semantically) a new participant, typically a new agent. However, firstly, a new participant with another semantic role can also be added, therefore this marker can also be used as an applicative, cf. (Peterson 1997; Jeong 2006). Secondly, there are also marginal non-valency-changing uses of the prefix rà-.

\subsection{Derivates with a causative meaning}

\subsubsection{Derivates with a causative meaning in general}

70 Most typically, rà-derivates have a causative meaning. It means that usually the prefix rà- has a different syntactic subject in comparison to the unprefixed verb it is derived from; the added subject has the semantic role of an agent or an effector.

\subsubsection{Causatives}

71 Causatives proper account for the majority of rà-derivates in the database (40 cases). The prefix rà- supplements an event with a new participant with the semantic role of an agent (if animate) or an effector (if inanimate) and with the syntactic role of a subject. The subject of an unprefixed verb from which the rà-causative is derived becomes a direct object of the rà-causative.

The overwhelming majority of unprefixed verbs from which the rà-causative are derived are INTRANSITIVE. See below for the four exceptions: two of them are reflexive verbs (i.e. they are formally transitive, but always have a reflexive pronoun as the formal direct object) and the other two are verbs of perception.

Similarly, the majority of unprefixed verbs from which the rà-causative are derived are UNCONTROLLED NON-AGENTIVE VERBS that initially have no agent valency and therefore easily add it to their argument structure. In the database there can be found eight verbs denoting an uncontrolled achievement, cf. (85-86), (87-88), three verbs for uncontrolled atelic processes, cf. (89-90), three verbs for uncontrolled accomplishments, cf. (91-92), four verbs for emotional states, cf. (93-94), six verbs for other states, cf. (95-96):

- dúlá 'drown (intr), go down, disappear' (H:72, 'disparaître dans l'eau, sombrer, se noyer’; T:

177, 's'enfoncer, se noyer') > ràdúlà 'sink, drown (tr)' (H:72, 'couler, immerger'; T:219, 'immerger, noyer'); 
- kísi ‘be saved from death' (C; T:177, 'être sauvé') > ràkísi ‘save from death' (C; T:221, ‘sauver de la mort');

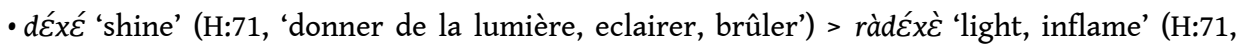
'allumer'; T:219, 'allumer');

- fúntú 'distend, swell up' (H:72, 'enfler, gonfler') > ràfúntù 'inflate, swell' (T:226, 'gonfler, faire enfler');

- gààxú 'be afraid of' (H:73, 'avoir peur de'; R:125, 'craindre, appréhender, avoir peur...') > ràgááxù 'frighten' (H:73, 'faire peur’; T:224, 'faire peur’; F:69, ‘ИСПуГАТЬ');

• bòròxó ‘be mild' (H:71, 'être mou') > ràbóròxò ‘make mild' (H:71, ‘amollir, assouplir’; T:230, 'ramolir, assouplir').

\begin{tabular}{|l|l|l|l|}
\hline$(85)$ & kúnkì & bárà & dúlá \\
\hline & ship & TRMN & drown \\
\hline & \multicolumn{3}{|c|}{ 'The ship went down.' (H:72) } \\
\hline
\end{tabular}

\begin{tabular}{|l|l|l|l|l|}
\hline$(86)$ & dímé-è & náxà & kúnkì & rà-dúlà \\
\hline & child-PL & CONS & ship & RA-drown \\
\hline & \multicolumn{4}{|l}{ 'The children sank the pirogue.' (H:72) } \\
\hline
\end{tabular}

\begin{tabular}{|l|l|l|l|l|}
\hline$(87)$ & ń & tàrá & bárà & kísí \\
\hline & I & elder_sibling & TRMN & be_saved \\
\hline & \multicolumn{4}{|c|}{ 'My brother was saved (from death).' (c) } \\
\hline
\end{tabular}

\begin{tabular}{|l|l|l|l|l|l|}
\hline (88) & ń & tàrá & bárà & ń & nà-kísì \\
\hline & I & elder_sibling & TRMN & I & RA-be_saved \\
\hline \multicolumn{4}{|l}{ 'My brother saved me (from death).' (C) } \\
\hline
\end{tabular}

\begin{tabular}{|l|l|l|l|}
\hline (89) & lánpuì & ná & déxć-fè \\
\hline & lamp & coP & shine-PROG \\
\hline & 'The lamp is on.' (Lit. 'The lamp is is shining.') (H:71) \\
\hline
\end{tabular}

\begin{tabular}{|l|l|l|l|l|l|l|}
\hline (90) & ń & má & díi & bárà & lánpuì & rà-déxè \\
\hline & I & at & child & TRMN & lamp & RA-shine \\
\hline \multicolumn{6}{|c|}{ 'My child turned on the lamp.' (F:68) } \\
\hline
\end{tabular}




\begin{tabular}{|l|l|l|l|l|l|}
\hline$(91)$ & ń & bèlèxé & bárà & fúntú & $=(69)$ \\
\hline & I & arm & TRMN & swell_up & \\
\hline & 'My arm swelled up.' (H:72) & \\
\hline
\end{tabular}

\begin{tabular}{|l|l|l|l|l|}
\hline (92) & fóyé & bárà & bélà & rà-fúntù \\
\hline & wind & TRMN & sail & RA-swell \\
\hline & \multicolumn{4}{|l}{ 'The wind swelled the sail.' (H:72) } \\
\hline
\end{tabular}

\begin{tabular}{|l|l|l|l|l|l|}
\hline (93) & í & námà & gààxú & bàré & rá \\
\hline & you & PROH & be_afraid & dog & with \\
\hline & \multicolumn{4}{|l}{ 'Don't be afraid of the dog.' (H:73) } \\
\hline
\end{tabular}

\begin{tabular}{|l|l|l|l|l|}
\hline (94) & fàtú & bárà & dùyćré & rà-gááxù \\
\hline & Fatu & TRMN & baby & RA-be_afraid \\
\hline & \multicolumn{3}{|l}{ 'Fatu frightened the baby.' (F:69) } \\
\hline
\end{tabular}

\begin{tabular}{|c|c|c|c|c|}
\hline (95) & yí & mángò-è & bóróxó-xì & $=(29)$ \\
\hline & this & mango-PL & be_mild-PRF & \\
\hline & \multicolumn{3}{|c|}{ 'These mangoes are soft.' (H:71) } & \\
\hline
\end{tabular}

\begin{tabular}{|l|l|l|l|}
\hline$(96)$ & í & bèlèx & rà-bóròxò \\
\hline & you & hand & RA-be_mild \\
\hline & \multicolumn{3}{|l|}{ 'Relax your hand.' (H:71) } \\
\hline
\end{tabular}

74 A significant number of unprefixed INTRANSITIVE CONTROLLED (AGENTIVE) VERBS also have ràcausatives. In the database there can be found 10 INTRANSITIVE TELIC CONTROLLED VERBS, cf. (97-98), (99-100), 2 INTRANSITIVE ATELIC CONTROLLED VERBS, cf. (101-102), 2 REFLEXIVE ATELIC CONTROLLED VERBS, cf. (103-104). But it is remarkable that there is a strong tendency for the rà-causatives of this group to trigger a reinterpretation of a controlled event as an uncontrolled one. This means that uncontrolledness is an almost obligatory feature of a rà-causative:

• sóó 'enter' > ràsóò ‘bring in' (Т:217, 'faire entrer’; F:69, ‘ВВЕСТИ, ВНЕСТИ’); 
- bìrá 'throw oneself down, fall' (C; H:89 'tomber') > ràbírà 'let fall' (C; T:218, 'faire tomber, rappeler a la memoire');

- bèré 'play' (H:70, 'jouer') > ràbérè 'play with, amuse' (H:70, 'faire jouer, amuser');

- gîi 'move(intr), run' (H:73, 'courrir', T:174, 'courir, fuir') > ràgî 'move, drive' (C; T:216, 'faire courir, faire fuir').

\begin{tabular}{|l|l|l|l|l|l|}
\hline$(97)$ & ń & bárà & sóó & bànxí & $=(67)$ \\
\hline & I & TRMN & enter & house & \\
\hline \multicolumn{7}{|c|}{ 'I came home / I entered the house.' (C) } & \\
\hline
\end{tabular}

\begin{tabular}{|l|l|l|}
\hline$(98)$ & pòótì & rà-sóò \\
\hline & cup & RA-enter \\
\hline & 'Bring the cup in.' (F:69) \\
\hline
\end{tabular}

\begin{tabular}{|l|l|l|l|l|l|l|}
\hline$(99)$ & ń & tàrá & bárà & bìrá & bóxì & fárì \\
\hline & I & elder_sibling & TRMN & throw_oneself & ground & on \\
\hline & \multicolumn{7}{|c}{ 'My brother threw himself on the ground.' (C) } \\
\hline
\end{tabular}

\begin{tabular}{|l|l|l|l|l|l|}
\hline$(100)$ & ń & tàrá & bárà & bònfó $\varepsilon$ & rà-bírà \\
\hline & I & elder_sibling & TRMN & bag & RA-throw_oneself \\
\hline & \multicolumn{3}{|c|}{ 'My brother let fall his bag.' (c) } \\
\hline
\end{tabular}

\begin{tabular}{|l|l|l|l|l|l|}
\hline$(101)$ & dímé-dí & ná & bèré-fè & búùl & rá \\
\hline & child-DIM & cop & play-PROG & ball & with \\
\hline & 'The chidren are playing ball.' (H:70) \\
\hline
\end{tabular}

\begin{tabular}{|l|l|l|l|l|}
\hline$(102)$ & kùlé-dí & ná & é & rà-bérè-fè \\
\hline & monkey-DIM & COP & 3PL & RA-play-PROG \\
\hline & 'The little monkey is amusing them', (H:70) \\
\hline
\end{tabular}

\begin{tabular}{|l|l|l|l|l|l|}
\hline (103) & sií & bárà & á & gíi & $=(24)$ \\
\hline & goat & TRMN & (s)he & run & \\
\hline
\end{tabular}


'The goat ran.' (F:40)

\begin{tabular}{|l|l|l|l|l|l|}
\hline$(104)$ & ń & ná & mà-tìnkàn-fè & wòtóò & rà-gîi-dè \\
\hline & I & COP & MA-study-PROG & car & RA-run-INF \\
\hline & 'I am learning to drive.' (C) \\
\hline
\end{tabular}

The database provides only 3 exceptional rà-causatives whose semantics presumes that the causee has some control over the event, cf. (105-106):

- gbilén 'come back' ( $\mathrm{T}: 183$, 'revenir, se retourner') > ràgbilèn 'make come back' (T:227, 'retourner, restituer'; F:69, 'ВозвРАТИТ');

- kàli ‘swear' (H:73, 'jurer'; T:180, 'jurer') > ràkáli 'make swear' (H:73, 'faire jurer'; T:220, 'faire jurer, prêter serment');

• sigá 'leave' > ràsígà 'send smb.' (H:74, 'faire partir, envoyer', T:222, 'faire partir').

\begin{tabular}{|l|l|l|l|l|l|}
\hline$(105)$ & é & bárà & gbilén & é & xònyí \\
\hline & they & TRMN & come_back & they & home \\
\hline \multicolumn{4}{|c|}{ 'They came back home.' (H:81) } \\
\hline
\end{tabular}

\begin{tabular}{|l|l|l|l|l|l|l|l|}
\hline$(106)$ & ń & sóxò & bárà & á & xá & gìnè & rà-gbílèn \\
\hline & I & uncle & TRMN & (s)he & POss & woman & RA-come_back \\
\hline \multicolumn{6}{|c|}{ 'My uncle made his wife come back.' (F:69) } \\
\hline
\end{tabular}

The only two transitive unprefixed verbs in the database that have rà-causatives are a VERB OF PERCEPTION, cf. (107-108), and a VERB OF MENTAL STATE, cf. (109-110). Both have no agentive valency in their frames. Syntactically rà-causatives derived from these verbs differ: ràtóo has the same object as the unprefixed verb (and the causee is not expressed) and ràkólòn makes the causee its syntactic object (and the object of the unprefixed verb is not expressed):

- tóó 'see' (C; T:175, 'voir, apercevoir') > ràtóo 'show' (C);

- kólón 'know, be acquainted with' (H:73, 'connaître'; T:182, 'connaître, savoir') > ràkólòn 'let know' (H:73, 'faire connaitre, avertir, prévenir'; T:227, 'informer, prévenir'; F:70: 'СоОБщАТЬ, СТАВИТЬ В ИЗВЕСТНОСТЬ').

\begin{tabular}{|l|l|l|l|l|l|l|}
\hline$(107)$ & ń & bárà & ń & tàrá & tóó & $=(63)$ \\
\hline & I & TRMN & I & elder_sibling & see & \\
\hline \multicolumn{6}{|l|}{ 'I saw my brother.' (C) } & \\
\hline
\end{tabular}




\begin{tabular}{|l|l|l|l|l|l|l|}
\hline$(108)$ & ń & tàrá & bárà & á & kòbé & rà-tóò \\
\hline & I & elder_sibling & TRMN & (s)he & occiput & RA-see \\
\hline & \multicolumn{7}{|l}{ 'My brother showed the back of his head.' (C) } \\
\hline
\end{tabular}

\begin{tabular}{|l|l|l|l|l|l|}
\hline$(109)$ & ń & mú & yí & kólón-mà & $=(36)$ \\
\hline & I & NEG & this & know-HABFUT & \\
\hline & \multicolumn{7}{|c|}{ 'I don't know this one.' (H:73) } & \\
\hline
\end{tabular}

\begin{tabular}{|l|l|l|l|l|l|}
\hline$(110)$ & é & náxà & xémé & bírín & rà-kólòn \\
\hline & they & cons & people & all & RA-know \\
\hline & \multicolumn{4}{|c|}{ 'They notified all the people.' (H:73) } \\
\hline
\end{tabular}

\subsubsection{Transitives}

The database provides five unprefixed LABILE VERBS OF STATE IN THEIR INTRANSITIVE USES AND OF CHANGE OF STATE IN THEIR TRANSITIVE USES that have rà-derivates with no apparent semantic difference from the transitive uses of the unprefixed verbs, cf. (111) \& (112-113). Presumably, this group of rà-derivates can be interpreted as rà-causatives derived from intransitive uses of the labile verbs:

• dذ̀xó 'put, seat, sit' (H:72, ‘poser, asseoir'; T:180, 's'asseoir') > ràdóxว̀ ‘put, seat' (H:72, 'poser dans un but bien déterminé'; T:219, 'raccorder, faire asseoir');

- findí 'become, turn, change' (H:72, 'passer d'un état dans un autre, devenir'; R:123, 'tourner, devenir'; T:189, 'devenir') > ràfíndì 'turn (tr), put' (H:72, 'changer d'état dans un but determiné, retourner qch., faire face à'; $\mathrm{T}: 225$, 'transformer');

- nóxó 'soil, be dirty' (T:178, 'salir'; H:90, 'être sale'; R:147, 'abîmer, tacher, salir') > rànóxò ‘soil' (T:221, 'salir');

- sáá 'put, lie down' (T:174, 'mettre, poser, coucher'; R:150, 'placer, mettre, deposer, se coucher') > ràsáà 'put' (T:217, 'coucher qch.');

- xìri 'attach, be attached' (H:73, 'attacher'; T:181, 'attacher, lier') > ràxírì 'unite, connect' (H:73, 'lier’; T:223, 'lier, raccorder, attacher').

\begin{tabular}{|l|l|l|l|l|}
\hline$(111)$ & é & dòxó-xì & nìngé & kántá-dè \\
\hline & they & sit-PRF & bull & look_after-INF \\
\hline & \multicolumn{4}{|c|}{ 'They are here to take care of the bulls.' (H:72) } \\
\hline
\end{tabular}

\begin{tabular}{|l|l|l|l|l|l|l|}
\hline$(112)$ & á & ná & kóté & dòxó-fè & sòóe & fárì \\
\hline
\end{tabular}




\begin{tabular}{|l|l|l|l|l|l|l|}
\hline & (s)he & COP & load & sit-PROG & horse & on \\
\hline & 'He is putting the load onto the horse's back.' (H:72) \\
\hline
\end{tabular}

\begin{tabular}{|l|l|l|l|l|l|l|l|l|}
\hline$(113)$ & í & xá & ná & kébényí-è & rà-dóxò & é & bóóré & rá \\
\hline & you & SBJV & COP & board-PL & RA-sit & they & REC & with \\
\hline \multicolumn{7}{|l}{ 'Let you lay these boards on one another.' (H:72) } \\
\hline
\end{tabular}

\subsection{Derivates with a benefactive meaning}

\subsubsection{Derivates with a benefactive meaning in general}

rà-benefactives add a valency of a beneficiary to the argument structure of the unprefixed verbs they are derived from. The syntactic status of the beneficiary may vary: with some ra-benefactives the beneficiary is an adjunct, with others it is a direct object. Most of the unprefixed verbs ( 4 of 5 in the database) that have rà-benefectives are CONTROLLED (AGENTIVE) VERBS.

\subsubsection{Benefactives with an adjunct beneficiary}

There are three unprefixed CONTROLLED TRANSITIVE TELIC VERBS (two of them are strictly transitive, one is a labile verb taken in the transitive meaning) in the database, that have rà-derivates which, having a benefactive meaning, provide a syntactically optional peripheral valency of a beneficiary expressed by the postposition bé 'to', cf. (114-115):

- tòlín 'twist' (H:74, 'faire des torsions'; T:184, 'tordre') > ràtólin 'twist for smb.' (H:74);

- bii 'cut, root out, shave' (H:70, 'couper (herbes), défricher, raser (poils)'; T:174, 'raser, sarcler') > ràbî 'cut, shave, root out for smb.' (H:70, 'se raser, défricher un endroit déterminé'; T:215, 'ouvrir, inaugurer');

- bálán 'close, be closed' (H:70, 'fermer, être fermé'; T:182, 'fermer') > ràbálàn 'close for smb.' (H:70).

\begin{tabular}{|l|l|l|l|l|l|}
\hline$(114)$ & á & ná & dùgí & tòlín-fè & $=(46)$ \\
\hline & (s)he & coP & cloth & twist & \\
\hline & 'She is squeezing the cloth.' (H:74) & \\
\hline
\end{tabular}

\begin{tabular}{|l|l|l|l|l|l|}
\hline$(115)$ & ń & xùnyí & rà-tólìn & ń & bé \\
\hline & I & head & RA-twist & I & to \\
\hline & 'Twist my head for me (i.e., braid my hair).' (H:74) \\
\hline
\end{tabular}




\subsubsection{Benefactives with an object beneficiary}

There are two unprefixed INTRANSITIVE VERBS (one of them is a controlled verb of process, while the other is an uncontrolled verb of state) in the database, which have rà-derivates with a benefactive meaning. These derivates have a direct object valency of a beneficiary, cf. (116-117), (118-119):

• sáli 'pray’ (Т:178, ‘prier’; F:67, ‘молиться’) > ràsáli ‘bless' (F:67, ‘ПРоводить молитвой, БлАГословить');

- jááxú 'be bad' (H:73, 'être mauvais, méchant'; T:185, 'être méchant') > rànááxù 'be malicious with smb.' (H:73, 'être méchant envers quelqu'un'; T:224, 'haïr, detester').

\begin{tabular}{|l|l|l|l|l|}
\hline$(116)$ & ń & bárà & sálí & $=(75)$ \\
\hline & I & TRMN & pray & \\
\hline & \multicolumn{3}{|c|}{ 'I prayed.' (F:66) } & \\
\hline
\end{tabular}

\begin{tabular}{|l|l|l|l|l|}
\hline (117) & sáliálìmámí & bárà & mùxú & rà-sálì \\
\hline & imam & TRMN & we.EXc & RA-pray \\
\hline & 'The imam blessed us.' (F:67) \\
\hline
\end{tabular}

\begin{tabular}{|l|l|l|l|l|}
\hline$(118)$ & yí & bàré & nááxú & $=(57)$ \\
\hline & this & dog & be_bad & \\
\hline & 'This dog is (permanently) angry.' (H:73) \\
\hline
\end{tabular}

\begin{tabular}{|l|l|l|l|l|l|}
\hline$(119)$ & yí & gìné & á & xúnyà & rà--nááxù \\
\hline & this & woman & (s)he & younger_sibling & RA-be_bad \\
\hline \multicolumn{4}{|c|}{ 'This woman is malicious with her younger brother.' (H:74) } \\
\hline
\end{tabular}

\subsection{Derivates with an abstract applicative meaning}

\subsubsection{Derivates with an abstract applicative meaning in general}

81 A number of unprefixed TRANSITIVE CONTROLLED TELIC VERBS in the database have ràderivates that add a new semantic valency of a specific purpose or manner. In the available data this valency is never expressed syntactically and is present only in the meaning of the rà-derivates of this group. 


\subsubsection{Applicatives specifying purpose}

Nine rà-derivates in the database derived from tRANSITIVE CONTROLLED TELIC VERBS are used to express actions performed with a specific purpose. It means that semantically (but not syntactically) a new purpose argument is added to the argument structure of the corresponding unprefixed verbs, cf. (120-121), (122-123):

• xàá 'wash' (H:73, 'laver'; T:175, 'laver') > ràxáà 'wash with a specific purpose’ (H:73; T:218, 'laver');

- bèndún 'drag, pull' (H:70, 'tirer'; T:191, 'tirer') > ràbéndùn 'drag, pull with a specific purpose' (H:70, 'tirer dans une intention bien déterminée');

- bònbó 'beat' (H:71, 'frapper'; T:189, 'frapper, battre') > ràbónbò 'beat to a certain target' (H:71 'frapper dans un but déterminé');

- dón 'eat' > ràdón 'eat with a specific purpose' (H:71, 'manger dans un but déterminé, remanger');

- fàlá 'say' (T:180, 'dire, tresser') > ràfálà 'arrange' (T:219 'préparer, arranger');

- fén 'look for' (H:72, 'aller chercher'; T:175, 'chercher') > ràfén 'look for with a specific purpose' (H:72);

- kòó ‘take down, take away' (H:73, 'enlever’; T:175, 'ramasser') > ràkój̀ ‘take away with a specific purpose' (H:73, 'enlever dans une intention déterminée'; T:216, 'ramasser, enlever');

- xín 'bite (once)' (T:176, 'mordre') > ràxín 'crack' ( $\mathrm{T}: 218$, 'couper avec les dents');

- fii ' 'give' > ràfî 'propose' (H:72, 'offrir').

\begin{tabular}{|l|l|l|l|l|l|}
\hline$(120)$ & á & sìgá-xì & dùgí- & xàá-dè & $=(59)$ \\
\hline & (s)he & leave-PRF & cloth-PL & wash-INF & \\
\hline & \multicolumn{3}{|l}{ 'She went to wash the clothes.' (H:73) } & \\
\hline
\end{tabular}

\begin{tabular}{|l|l|l|l|l|l|l|l|}
\hline$(121)$ & $i$ & $b$ c̀lèxé & rà-xáà, & wón & fá & bàndé & dón \\
\hline & you & hand & RA-wash & we.INC & come & rice & eat \\
\hline & 'Wash your hands, we are going to eat rice.' (H:73) & & \\
\hline
\end{tabular}

\begin{tabular}{|l|l|l|l|l|l|}
\hline$(122)$ & á & náxà & yèlibá-è & fén & $=(71)$ \\
\hline & (s)he & cons & griot-PL & look_for & \\
\hline & \multicolumn{3}{|l}{ 'He went to look for griots.' (H:72) } & \\
\hline
\end{tabular}

\begin{tabular}{|l|l|l|l|l|l|l|}
\hline$(123)$ & i & námà & ń & rà-fén & gèré & rá \\
\hline & you & PROH & I & RA-look_for & quarrel & with \\
\hline \multicolumn{7}{|c|}{ 'Don't look for me with the purpose of a quarrel.' (H:72) } \\
\hline
\end{tabular}




\subsubsection{Applicatives specifying manner}

Similarly, three rà-derivates in the database derived from TRANSITIVE CONTROLLED TELIC VERBS are used to express actions performed in a specific manner, cf. (124-125):

• bذ̀ó 'cut, tear' (H:71, ‘séparer, fendre, déchirer'; T:175, ‘déchirer') > ràbój ‘cut up’ (H:71; T: 215 , 'entailler, éventer');

• dégé 'sew' (H:71, 'coudre'; R:119, 'coudre') > ràdégè 'sew in a particular way' (H:71, 'coudre un sac plein, découdre, ficeler un rôti');

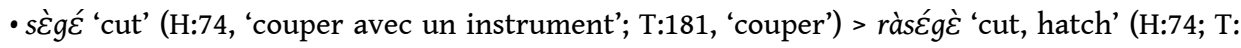
221, 'éclore, couper').

\begin{tabular}{|l|l|l|l|l|l|l|l|}
\hline (124) & $\grave{a}$ & bárà & ń & má & dònmá & bòó & $=(16)$ \\
\hline & (s)he & TRMN & I & at & boubou & tear & \\
\hline \multicolumn{6}{|l}{ 'He tore my boubou.' (H:71) } \\
\hline
\end{tabular}

\begin{tabular}{|c|c|c|c|}
\hline (125) & 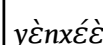 & rà-bój & \\
\hline & fish & RA-tear & \\
\hline & \multicolumn{3}{|c|}{ 'Cut up the fish.' (H:71) } \\
\hline
\end{tabular}

\subsection{Derivates with non-valency-changing meanings}

84 A few rà-derivates in the database have the same argument structure as the unprefixed verbs they are derived from. These include semelfactives and fully idiomatic derivates.

\subsubsection{Semelfactives}

Two unprefixed TRANSITIVE CONTROLLED MULTIPLICATIVE VERBS in the database have ràderivates with a semelfactive meaning. This means that a rà-derivate designates a subevent from the series of sub-events expressed by the corresponding unprefixed verb, cf. (126-127). Since the database contains no other rà-derivates from transitive multiplicative verbs, one can assume that this meaning is standard for them:

- bórón ‘trample, move one’s legs' (H:71, 'agir avec des pieds'; T:182, 'piétiner') > ràbóròn (H:71

'donner un coup de pied'; F:69, 'ПинАть');

- dìn 'pound' (H:72, 'donner des coups, piler'; T:176, 'piler, heurter, cogner') > ràdín 'pound once' (H:72, 'heurter, bousculer, pousser devant soi'; T:217, 'heurter, pousser'; F:68, 'ТОЛКАТЬ').

\begin{tabular}{|l|l|l|l|l|l|l|}
\hline$(126)$ & á & $n a ́$ & $a ́$ & $x a ́$ & $k u ̀ r \varepsilon ́$ & bórón-fé \\
\hline & (s)he & cop & (s)he & POss & bicycle & trample-PROG \\
\hline & \multicolumn{7}{|c|}{ 'He is riding his bicycle.' (Lit. 'He is trampling his bicycle.') (H:71) } \\
\hline
\end{tabular}




\begin{tabular}{|l|l|l|l|l|}
\hline (127) & Fódé & bárà & báré & rà-bóròn \\
\hline & Fode & TRMN & dog & RA-trample \\
\hline & \multicolumn{4}{|l}{ 'Fode kicked the dog.' (F:69) } \\
\hline
\end{tabular}

\subsubsection{Fully idiomatic derivates}

There are three unprefixed TRANSITIVE CONTROLLED TELIC VERBS in the database that have fully idiomatic rà-derivates, i.e. there is no synchronic semantic correlation between ràderivates and the unprefixed verbs they are derived from, cf. (128-129):

- báá ‘take down, pick' (Т:174 'puiser, cueillir, ôter’; F:66, ‘СРЫВАТь') > ràbáà ‘do' (Т:215, 'faire’; $\mathrm{F}: 66$, 'СДЕЛАТЬ');

- tálá 'pull out (once)?' (T:178, 'arracher') > ràtálà 'unreel, spread out' (T:222, 'étendre, dérouler');

• sذ̀tó 'get, obtain' (T:181, 'recevoir, obtenir’) > ràsótò ‘offend, insult' (T:222, 'insulter').

\begin{tabular}{|l|l|l|l|}
\hline$(128)$ & mómó & mángò-è & báá-fè \\
\hline & Momo & mango-PL & pick-PROG \\
\hline & 'Momo is picking mangoes.' (F:66) \\
\hline
\end{tabular}

\begin{tabular}{|l|l|l|l|l|}
\hline (129) & á & bárà & wàlí & rà-báà \\
\hline & (s)he & TRMN & work & RA-pick \\
\hline & \multicolumn{3}{|l}{ 'He did the work.' (F:66) } \\
\hline
\end{tabular}

\subsection{Prefix rà-: conclusion}

Other rà-causatives are derived as follows:

- rà-causatives can be derived from conrolled intransitive verbs, but in this case there is a strong tendency for the event to be reinterpreted as an uncontrolled one;

- rà-causatives can be derived from a marginal group of uncontrolled transitive stative verbs;

- labile verbs of state in their intransitive uses and verbs of change of state in their transitive uses derive rà-causatives from their intransitive meaning, and these derivates have therefore no apparent semantic difference with their transitive uses.

Controlled transitive telic verbs have rà-derivates with other meanings, and the distribution of these meanings is mainly lexical:

- some transitive telic verbs derive rà-benefactives; 
- some transitive telic verbs derive rà-applicatives specifying purpose;

- some transitive telic verbs derive rà-applicatives specifying manner;

- some transitive telic verbs derive fully idiomatic rà-derivates.

There is also a small group of intransitive unprefixed verbs that derive rà-benefactives.

91 Admittedly, there are no rà-derivates in the database that are derived from transitive verbs of non-mentioned semantic types - e.g. atelic agentive verbs, telic effector verbs. Such derivates may be impossible in Susu, but this requires further research.

\section{Conclusion}

A description of the meanings of the two most productive verbal prefixes in Susu, màand rà-, has been given in this paper. It has been shown that both prefixes have core meanings and more marginal meanings. Core meanings that are held by the majority of the prefixed derivates strongly correlate with lexical semantic features of the verbal stems they are derived from. More marginal meanings have weaker correlations, and are frequently defined lexically.

\section{BIBLIOGRAPHY}

\section{Sources}

C - consultant, F - (Fofana 1992), H - (Houis 1963), R - (Raimbault 1923), T - (Touré 1994).

\section{References}

BAILleul Charles, 1986, « Sens originel des postpositions en Bambara », Mandenkan 11, pp. 71-74.

CUsIC David D., 1981, Verbal plurality and aspect, Stanford: Stanford University (Ph.D. dissertation).

DOWTY David, 1991, “Thematic proto-roles and argument selection”, Language 67(3), pp. 547-619.

FOFANA Mori-Saidu, 1992, Sintaksis prostogo predloženija v jazyke analitičeckogo tipa (na materiale jazyka soso) [Syntax of a simple sentence in an analytic language (the Soso case)], Moscow, Institute of Linguistics RAS. (Ph.D. dissertation.) $=\mathbf{F}$

HouIs Maurice, 1963, Étude descriptive de la langue Susu, Dakar, Université de Dakar. = H JEONG Youngmi, 2006, The landscape of applicatives, College Park, University of Maryland (Ph.D. dissertation).

KËTA Boniface, 1989, « Les préverbes du dialonké », Mandenkan 17, pp. 69-80. 
LÜPKE Friederike, 2005, A grammar of Jalonke argument structure Nijmegen, Radboud Universiteit (Ph.D. dissertation).

PETERSON David, 1997, Discourse-functional, historical, and typological aspects of applicative constructions, Leipzig, MPI-EVA (Ph.D. dissertation).

RAIMBAUlt R. P., 1923, Dictionnaire Français-Soso et Soso-Français, Rome, Sodalité de St. Pierre Claver.

$=\mathbf{R}$

Shluinsky [šLUINSKIJ] Andrej B., 2010, "Vse puti vedut v Rim, ili o pokazateljax ma v jazyke Susu [All roads lead to Rome, or On the ma markers in Susu], in DEM'JANKOV Valerij, PORXOMOVSKIJ, Viktor (eds.), V prostranstve jazyka i kul'tury: zvuk, znak, smysl. K 70-letiju V. A. Vinogradova, Moscow, Jazyki slavjanskix kul'tur, pp. 317-331.

TOURÉ Aboubacar, 1994, Éléments de description de la langue Soso, Grénoble, Université de Grénoble. (Thèse de doctorat.) $=\mathbf{T}$

VYDRIN Valentin F., 2009, "Preverby v jazyke dan-gueta” [Preverbs in Dan-Gweta], Voprosy jazykoznanija 2, pp. 75-84.

VYDRINA Aleksandra V., 2009a, “Pokazatel' glagol'noj množestvennosti v jazyke kakabe” [A marker of the verbal plurality in Kakabe], in VYDRIN Valentin F. (ed.), Afrikanskij sbornik 2009,

St. Petersburg, Museum of Anthropology and Ethnography, pp. 269-288.

VYDRINA Aleksandra V., 2009b, Argumentnaja struktura i aktantnye derivacii v jazyke kakabe [Argument structure and valency-changing derivations in Kakabe], St. Petersburg, St. Petersburg State University (M.A. dissertation.)

wooD Esther J., 2007, The semantic typology of pluractionality, Berkeley, University of California.

(Ph.D. dissertation.)

\section{NOTES}

1. I am very indebted to Oumar Camara with whom I worked extensively in Moscow in autumn 2004 and in winter and spring 2007.

2. Exact quotations of the meaning of the verbs as given in the referenced publication are given in the brackets, except for frequently used verbs with clear meaning.

3. One more mental state in the database, xónó 'get angry', has a strongly idiomatic mà-derivate.

4. There is just one exceptional event with an incremental theme in the database, dón 'eat', that has a strongly idiomatic mà-derivate.

\section{ABSTRACTS}

This paper presents a systematic analysis of the available data related to the two most productive verbal prefixes in Susu, mà- and rà-. On the one hand, each of the two prefixes has a number of semantically interrelated meanings, and the choice of a particular meaning depends, to a 
significant extent, on the lexical semantic features of the verbal stem. On the other hand, there are many lexicalized uses of both prefixes.

L'article offre un analyse systématique des données disponibles concernant les deux préfixes verbaux les plus productifs de la langue susu, mà- et rà-. D'une part, chacun de ces préfixes a un ensemble de sens mutuellement liés, et le choix du sens dépend largement des caractéristiques sémantiques de la base verbale. D'autre part, chacun des préfixes manifeste de nombreux emplois lexicalisés.

В СТАТЬЕ СИСТЕМАТИЗИРОВАНЫ ДАННЫЕ ОБ УПОТРЕБЛЕНИИ ДВУХ НАИБОЛЕЕ ПРОДУКТИВНЫХ ГЛАГОЛЬНЫХ ПРИСТАВОК В ЯЗЫКЕ СУСУ, mà- И rà-. С ОДНОЙ СТОРОНЫ, У КАЖДОЙ ИЗ ПРИСТАВОК ПРЕДСТАВЛЕН НАБОР ВЗАИМОСВЯЗАННЫХ ЗНАЧЕНИЙ, ПРИЧЕМ ВЫБОР ЗНАЧЕНИЯ В ЗНАЧИТЕЛЬНОЙ МЕРЕ ОПРЕДЕЛЯЕТСЯ СЕМАНТИЧЕСКИМИ ПРИЗНАКАМИ ГЛАГОЛА. С ДРУГОЙ СТОРОНЫ, У КАЖДОЙ ИЗ ПРИСТАВОК ЕСТЬ МНОГОЧИСЛЕННЫЕ ЛЕКСИКАЛИЗОВАННЫЕ УПОТРЕБЛЕНИЯ.

\section{INDEX}

Keywords: Susu, Verbal Prefixes, Lexical Semantics, Pluractionality, Valency-changing, Argument Structure motsclesru ЯЗЫК СУСУ, ГЛАГОЛЬНЫЕ ПРИСТАВКИ, ЛЕКСИЧЕСКАЯ СЕМАНТИКА, ПРЕДИКАТНАЯ МНОЖЕСТВЕННОСТЬ, АКТАНТАНАЯ ДЕРИВАЦИЯ, АРГУМЕНТНАЯ СТРУКТУРА Subjects: soussou Mots-clés: préfixes verbaux, sémantisme lexical, pluriactionnalité, structure argumentale

\section{AUTHOR}

\section{ANDREY SHLUINSKY}

Institute of Linguistics, Russian Academy of sciences, Moscow ashl@yandex.ru 